\title{
Abnormal small heat shock protein interactions involving neuropathy-associated HSP22 (HSPB8) mutants
}

\author{
Jean-Marc Fontaine, ${ }^{*}$ Xiankui Sun, ${ }^{*}$ Adam D. Hoppe, ${ }^{\dagger}$ Stephanie Simon, ${ }^{\ddagger}$ \\ Patrick Vicart, ${ }^{\ddagger}$ Michael J. Welsh, ${ }^{*}$ and Rainer Benndorf*,1 \\ Departments of *Cell and Developmental Biology, and ${ }^{\dagger}$ Microbiology and Immunology, University of \\ Michigan Medical School, Ann Arbor, Michigan, USA; and ${ }^{\ddagger}$ EA 300 Stress et Pathologies du \\ Cytosquelette, Université Paris 7, UFR de Biochimie, Paris, France
}

ABSTRACT Two mutations (K141E, K141N) in the small heat shock protein (sHSP) HSP22 (HSPB8) are associated with the inherited peripheral motor neuron disorders distal hereditary motor neuropathy type II and axonal Charcot-Marie-Tooth disease type $2 \mathrm{~L}$. HSP22 is known to form homodimers, heterodimers with other sHSPs, and larger oligomers. In an effort to elucidate the cellular basis for these diseases, we have determined the ability of mutant HSP22 to interact with itself, with wild-type HSP22, and with other SHSPs that are abundant in neurons. Using the yeast two-hybrid method, quantitative fluorescence resonance energy transfer in live cells, and cross-linking, we found aberrantly increased interactions of mutant HSP22 forms with themselves, with wild-type HSP22, and with the other sHSPs, $\alpha$ B-crystallin, and HSP27. Interaction with HSP20 was not affected by the mutations. The data suggest that each mutant form of HSP22 has a characteristic pattern of abnormal interaction properties. A mutation (S135F) in HSP27 that is also associated with these disorders showed increased interaction with wild-type HSP22 also, suggesting linkage of these two etiologic factors, HSP22 and HSP27, into one common pathway. Increased interactions involving mutant sHSPs may be the molecular basis for their increased tendency to form cytoplasmic protein aggregates, and for the occurrence of the associated neuropathies.-Jean-Marc Fontaine, Xiankui Sun, Adam D. Hoppe, Stephanie Simon, Patrick Vicart, Michael J. Welsh, and Rainer Benndorf. Abnormal small heat shock protein interactions involving neuropathy-associated HSP22 (HSPB8) mutants. FASEB J. 20, E1579-E1588 (2006)

Key Words: distal hereditary motor neuropathy $\cdot$ CharcotMarie-Tooth disease $\cdot$ fluorescence resonance energy transfer

PAtients WITH THE inherited peripheral neuropathies distal hereditary motor neuropathy (dHMN) and axonal Charcot-Marie-Tooth disease (CMT) suffer progressive weakness and atrophy of the muscles, initially in the lower limbs and later also in the distal upper limbs (1). Patients with CMT have, in addition to the motor abnormalities, also sensory abnormalities. Currently, there is no cure for these disorders. Both disorders are clinically and genetically heterogeneous, and the number of identified genes that, when mutated, cause these diseases has risen substantially in recent years $(2,3)$. Among the affected genes is the gene encoding the small heat shock protein (sHSP) 22 (HSP22, also known as HSPB8, H11; gene name: $H S P B 8)(4,5)$. So far, five families with dHMN type II or CMT type 2L carrying mutations in the HSPB8 gene have been identified $(6,7)$. The two mutations known to date affect the "hot spot" amino acid residue Lys141 in the wild-type HSP22 ( ${ }^{\text {wt }} \mathrm{HSP} 22$ ) protein sequence changing it to either Glu $\left({ }^{\mathrm{K} 141 \mathrm{E}} \mathrm{HSP} 22\right)$ or Asn ( $\left.{ }^{\mathrm{K} 141 \mathrm{~N}} \mathrm{HSP} 22\right)$. In affected individuals, both the wild-type and mutant HSPB8 alleles are expressed, and both mutants have dominant gain-of-function characteristics (6).

In mammals, several of the sHSPs such as HSP22, HSP27, $\alpha$ B-crystallin ( $\alpha$ B-Cry), and HSP20 are expressed in a variety of organs and tissues, including neuronal tissues (8). sHSPs form dimers that are the basic building blocks for higher molecular mass oligomeric structures or complexes $(9,10)$. In addition to homodimers, sHSPs can form heterodimers and mixed heterooligomers, although not all possible sHSP interactions may occur in cells $(11,12)$. Most cells contain sHSP species ranging from dimers to approximately quadragintamers. This mixed complex formation is a prominent, although not well understood, property of sHSPs. HSP22 has been shown to form homodimers and also heterodimers with HSP27, $\alpha$ B-Cry, HSP20, and other sHSPs $(12,13)$. Recently, a number of mutations in HSP27 ( ${ }^{\mathrm{mu}} \mathrm{HSP} 27$ ) and $\alpha \mathrm{B}-\mathrm{Cry}$ has been identified that are also associated with neuropathies and with myopathies. These mutations include ${ }^{\mathrm{R} 127 \mathrm{~W}} \mathrm{HSP} 27$,

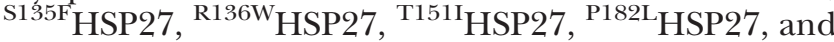
${ }^{\mathrm{P} 182 \mathrm{~S}} \mathrm{HSP} 27$ (all associated with $\mathrm{dHMN}$ and/or CMT), ${ }^{\mathrm{R} 120 \mathrm{G}} \alpha \mathrm{B}-\mathrm{Cry},{ }^{464 \Delta \mathrm{CT}} \alpha \mathrm{B}-\mathrm{Cry}$, and ${ }^{\mathrm{Q} 151 \mathrm{X}} \alpha \mathrm{B}-\mathrm{Cry}$ (all associated with desmin-related or myofibrillar myopathy), and ${ }^{\mathrm{R} 157 \mathrm{H}} \alpha \mathrm{B}-\mathrm{Cry}$ (associated with dilated cardiomyopathy) $(14-19)$.

\footnotetext{
${ }^{1}$ Correspondence: Department of Cell and Developmental Biology, University of Michigan Medical School, 109 Zina Pitcher Pl., Ann Arbor, MI 48109-2200, USA. E-mail: rbenndo@umich.edu doi: 10.1096/fj.06-5911fje
} 
A hallmark of many neurodegenerative diseases, including Parkinson, Alzheimer, and Alexander diseases, is the misfolding and precipitation of proteins in the nervous system referred to as aggresome or amyloid formation (20). Each such amyloid disease usually involves the aggregation of a specific protein, with a range of other proteins being also incorporated into the aggregates. sHSPs are found in at least one type of these aggregates together with intermediate filament proteins (21). As far as studied, the neuropathy- and myopathy-associated mutant forms of HSP22, HSP27, and $\alpha \mathrm{B}$-Cry also form aggregates, which is thought to contribute to the manifestation of the associated diseases $(6,14,22,23)$.

Using the yeast two-hybrid (TH) method, chemical cross-linking (CL), and quantitative fluorescence resonance energy transfer (qFRET) in live mammalian cells, we show herein that both mutant HSP22 $\left({ }^{\mathrm{mu}} \mathrm{HSP} 22\right)$ proteins are capable of interacting with themselves, with ${ }^{\text {wt }} \mathrm{HSP} 22$, and with other sHSPs, and that the ${ }^{\mathrm{mu}} \mathrm{HSP} 22$ proteins have abnormally increased, although different, interaction properties. Similarly, disease-associated ${ }^{5135 \mathrm{~F}} \mathrm{HSP} 27$ has an increased interaction with ${ }^{\text {wt }} \mathrm{HSP} 22$ as compared with wild-type HSP27 $\left({ }^{\text {wt }} \mathrm{HSP} 27\right)$, thus providing a rationale for the observation that mutations in both, HSP22 $\left({ }^{\mathrm{K} 141 \mathrm{E}} \mathrm{HSP} 22\right.$, $\left.{ }^{\mathrm{K} 141 \mathrm{~N}} \mathrm{HSP} 22\right)$ and HSP27 ( $\left.{ }^{\mathrm{S} 135 \mathrm{~F}} \mathrm{HSP} 27\right)$ result in similar disease phenotypes.

It is hypothesized that these abnormal sHSP interactions are the molecular basis for both the formation of cytoplasmic protein aggregates and eventually for the development of the associated disorders dHMN type II and CMT type 2.

\section{MATERIALS AND METHODS}

\section{Vector constructs}

TH vector constructs were made using the vectors pGBKT7, pGADT7, and pACT2 (BD Biosciences, San Jose, CA). Cyan (CFP) and citrine (CIT) fluorescent sHSP fusion protein expression vectors were made using the vectors peCFPN1 (BD Biosciences) and peCITN1 (24). myc-HSP22 constructs were made using the vectors pcDNA3.1-myc (Invitrogen, Carlsbad, CA). The mutant forms of HSP22 were made by site-directed mutagenesis using the QuickChangeXL kit (Stratagene, La Jolla, CA). More detailed cloning information is given in Table 1 and in previous publications $(12,13,25)$.

\section{Two-hybrid method}

Small-scale sequential transformation of the yeast strain AH109 was performed as described in the manufacturer's instructions (BD Biosciences). The yeast was first transformed with constructs pGBKT7- ${ }^{\mathrm{wt}} \mathrm{HSP} 22$ [13] (the underlined numbers in brackets designate the used vector constructs as specified in Table 1), pGBKT7- ${ }^{\mathrm{K} 141 \mathrm{E}} \mathrm{HSP} 22$ [둘 $]$, or pGBKT7${ }^{\mathrm{K} 141 \mathrm{~N} H S P 22}$ [17], and grown on -Trp medium as described previously (13). In the second step, the yeast were transformed with the complementary vectors, as specified in Figs. $2 A, 5 A$, and $7 A$. Selection was on -Trp,-Leu,-His medium for the phenotype His + (growth). Additionally, the colonies were analyzed for the phenotype LacZ+ (blue color) using the colony filter lift assay. The interaction assays were considered positive only if both reporter genes were activated. For the negative $\mathrm{TH}$ controls, yeasts were transformed with each vector alone and tested on -Trp/-Leu/-His medium (not shown). Additionally, yeasts were cotransformed with each vector and with the "empty" partner vector (controls C1-C14 in Figs. $2 B, 5 B, 7 B$ ). In none of these controls were the reporter genes activated.

\section{Live cell imaging and quantitative fluorescence resonance energy transfer (qFRET)}

CFP- and CIT-sHSP fusion protein expression vectors were used for these experiments. CIT is a variant of the yellow fluorescent protein (YFP) that is superior for qFRET (24). COS-7 cells were grown in glass-bottom six-well culture plates (MatTek Corporation, Ashland, MA) in Dulbecco's modified Eagle medium (DMEM) (Life Technologies, Inc., Carlsbad, CA) supplemented with $10 \%$ fetal calf serum (Invitrogen) in a $5 \% \mathrm{CO}_{2}$ humidified atmosphere at $37^{\circ} \mathrm{C}$. Cells were transfected at $\sim 60 \%$ confluency with $0.75 \mu \mathrm{g}$ (single construct) or $1.5 \mu \mathrm{g}$ (two constructs) vector DNA using FuGene6 (Roche Applied Science, Indianapolis, IN). Twenty-four h later, the live cells that express the CFP- and CIT-sHSP fusion proteins were washed 2 times with PBS and kept in DMEM medium without phenol red (Invitrogen) for collecting the fluorescence images at $37^{\circ} \mathrm{C}$.

For fluorescence imaging, an inverted epifluorescence microscope (Eclipse TE-2000 U; Nikon, Melville, NY) equipped with a $100 \mathrm{~W}$ Mercury Arc-lamp, exciter filters 430/25 and 500/20, a dichroic microscope filter 86002bs, and with a 505dcxr Dual View Micro Imager MSMI.DV.CC (Optical Insights, Tucson, AZ) with the emission filters $470 / 30$ and 535/30, was used. Images were collected by a digital CoolSnap CCD camera (Photometrics, Huntington Beach, CA) and using Metamorph image processing software version 6.2r5 (Molecular Devices, Sunnyvale, CA).

HSP22-CIT fusion proteins (both wild-type and mutants) expressed in COS-7 cells formed aggregates. The proportion of cells with aggregates was determined $24 \mathrm{~h}$ after transfection. For counting, randomly selected microscopic fields were evaluated using a Plan fluor ELWD 40x/0.6 objective lens (Nikon).

We applied the qFRET method to quantify apparent fluorescence resonance energy transfer efficiencies as indicators of protein interactions $(24,26)$. The configuration of the microscope was as described above, with the exception that a Fluor ELWD 40x/1.3 oil Dic H objective lens (Nikon) was used. $I_{\mathrm{A}}, I_{\mathrm{D}}$, and $I_{\mathrm{F}}$ images from at least 30 microscopic fields per sample group were acquired and background/shadingcorrected prior to computation by the qFRET algorithm. The apparent FRET efficiencies $E_{\mathrm{A}}$ and $E_{\mathrm{D}}$ were determined $\left(E_{\mathrm{A}}\right.$, apparent acceptor efficiency calculated from sensitized emission and dependent on the fraction of acceptor in complex; $E_{\mathrm{D}}$, apparent donor efficiency calculated relative to donor fluorescence and dependent on the fraction of the donor in complex). $E_{\mathrm{A}}$ and $E_{\mathrm{D}}$ are proportional to the fraction of the interaction partners in complex. The calculated output data were expressed as the apparent average fluorescence resonance energy transfer efficiency, or $\operatorname{AAFE}\left(\left[E_{\mathrm{A}}+E_{\mathrm{D}}\right] / 2\right)$. Only cells without protein aggregates were included in this analysis. As negative control, the cells were transfected with the "empty" CFP (peCFPN1) and CIT (peCITN1) vectors. Expression of the corresponding fluorescent proteins resulted in a minor interaction signal that defined the baseline level. AAFE values that were significantly different from that signal indicated interaction. 


\begin{tabular}{|c|c|c|c|c|}
\hline Construct & Construct Designation & Method of Cloning/Source of sHSP cDNA & $\begin{array}{l}\text { Restriction } \\
\text { Sites Used }\end{array}$ & Primers $^{a}$ \\
\hline \multicolumn{5}{|l|}{ Number } \\
\hline 1 & pcDNAmyc- ${ }^{\mathrm{wt}} \mathrm{HSP} 22$ & described previously $^{b}$ & - & - \\
\hline$\underline{2}$ & pcDNAmyc- ${ }^{\mathrm{K} 141 \mathrm{E}} \mathrm{HSP} 22$ & site-directed mutagenesis of construct $\underline{1}$ & - & 1,2 \\
\hline$\underline{\overline{3}}$ & pcDNAmyc- ${ }^{\mathrm{K} 141 \mathrm{~N}} \mathrm{HSP} 22$ & site-directed mutagenesis of construct 1 & - & 3,4 \\
\hline$\underline{4}$ & peCITN1- ${ }^{\mathrm{wt}} \mathrm{HSP} 22$ & PCR of construct $\underline{1}$, TopoTA cloning & EcoRI, KpnI & 5,6 \\
\hline$\underline{\overline{5}}$ & peCFPN1- ${ }^{\mathrm{wt}} \mathrm{HSP} 22$ & PCR of construct $\underline{1}$, TopoTA cloning & EcoRI, $K p n \mathrm{I}$ & 5,6 \\
\hline$\underline{\overline{6}}$ & peCITN1- ${ }^{\mathrm{K} 141 \mathrm{E}} \mathrm{HSP} 22$ & PCR of construct $\underline{2}$, TopoTA cloning & EcoRI, $K p n \mathrm{I}$ & 5,6 \\
\hline$\underline{7}$ & peCFPN1- ${ }^{\mathrm{K} 141 \mathrm{E}} \mathrm{HSP} 22$ & PCR of construct $\underline{2}$, TopoTA cloning & EcoRI, KpnI & 5,6 \\
\hline$\underline{8}$ & peCITN1- ${ }^{\mathrm{K} 141 \mathrm{~N}} \mathrm{HSP} 22$ & PCR of construct $\underline{3}$, TopoTA cloning & EcoRI, KpnI & 5,6 \\
\hline$\underline{\overline{9}}$ & peCFPN1- ${ }^{\mathrm{K} 141 \mathrm{~N}} \mathrm{HSP} 22$ & PCR on construct $\underline{3}$, TopoTA cloning & EcoRI, $K p n \mathrm{I}$ & 5,6 \\
\hline$\underline{10}$ & peCFPN1-HSP20 & PCR of pAS2-1-HSP20 $2, \mathrm{D}$, TopoTA cloning & EcoRI, KpnI & 7,8 \\
\hline 11 & peCFPN1- $\alpha$ B-Cry & described previously ${ }^{c}$ & & \\
\hline$\underline{12}$ & peCFPN1-wt HSP27 & described previously ${ }^{b}$ & - & - \\
\hline$\underline{13}$ & pGBKT7-wt HSP22 & subcloning of pACT2- ${ }^{\mathrm{wt}} \mathrm{HSP} 22^{b}$ & NdeI, EcoRI & - \\
\hline$\underline{14}$ & pGADT7-wt HSP22 & subcloning of pACT2- ${ }^{\text {wt }} \mathrm{HSP} 22^{b}$ & NdeI, EcoRI & - \\
\hline$\underline{15}$ & pGBKT7- ${ }^{\mathrm{K} 141 \mathrm{E}} \mathrm{HSP} 22$ & site-directed mutagenesis of construct $\underline{13}$ & - & 1,2 \\
\hline$\underline{16}$ & pGADT7- ${ }^{\mathrm{K} 141 \mathrm{E}} \mathrm{HSP} 22$ & site-directed mutagenesis of construct $\underline{14}$ & - & $1, \overline{2}$ \\
\hline 17 & pGBKT7- ${ }^{\mathrm{K} 141 \mathrm{~N}} \mathrm{HSP} 22$ & site-directed mutagenesis of construct $\underline{13}$ & - & 3,4 \\
\hline$\underline{18}$ & pGADT7-K141N HSP22 & site-directed mutagenesis of construct 14 & - & 3,4 \\
\hline$\underline{19}$ & pACT2- ${ }^{\mathrm{wt}} \mathrm{HSP} 27(\mathrm{a})^{e}$ & described previously $^{d}$ & - & - \\
\hline$\underline{20}$ & pACT2-HSP20 & described previously $^{d}$ & - & - \\
\hline$\underline{\underline{21}}$ & pACT2- $\alpha$ B-Cry ${ }^{e}$ & described previously $^{c}$ & - & - \\
\hline$\overline{22}$ & pACT2-wt HSP27(b) ${ }^{e}$ & PCR of construct $\underline{19}$ & EcoRI, XhoI & 9,10 \\
\hline$\overline{23}$ & pACT2- ${ }^{\mathrm{S} 135 \mathrm{~F}} \mathrm{HSP} 27^{e}$ & site-directed mutagenesis of construct 22 & - & 11,12 \\
\hline$\overline{24}$ & peCITN1- ${ }^{\mathrm{wt}} \mathrm{HSP} 27$ & PCR of construct $\underline{12}$ & EcoRI, HindIII & 13,14 \\
\hline$\underline{25}$ & peCITN1-S135F HSP27 & site-directed mutagenesis of construct 24 & - & 11,12 \\
\hline
\end{tabular}

${ }^{a}$ For each primer pair, the first and second numbers refer to the forward and reverse primers, respectively. Primers: 1, 5'ctaagaacttcacagagaaaatccagcttcctgc; 2, 5' -gcaggaagctggattttctctgtgaagttcttag; $5^{\prime}$-gtttctaagaacttcacaaacaaaatccagcttcctgcagagg; 4, 5'-cctctgcaggaagctggattttgtttgtgaagttcttagaaac; 5, 5'-agaacttcacaaacaaaatccagct; 6, 5'-agctggattttgtttgtgaagttct; 5, 5'-ccggaattcagtgtggtggaattcaac; 6, 5'-cggggtacccaggtacaggtgacttcc; 7, 5'-ccggaattcatggagatccctgtgcctg; 8, 5'-cggggtacccacttggctgcggctggcg; 9, 5'-aaaaaagaattcgaatgaccgagcgcc; 10, 5'aaaaaactcgagctcacttggcggcag; 11，5'-atggctacatcttccggtgcttcacg; 12, 5'-tgaagcaccggaagatgtagccatgc; 13， 5'-aaaaaaaagcttatgaccgagcgccgc; 14, $5^{\prime}$-aaaaagaattcgcacttggcggcagt. $\quad{ }^{b}$ Sun et al., 2004 (13). $\quad{ }^{c}$ Fontaine et al., 2005 (12). ${ }^{d}$ Sun et al., 2006 (25). ${ }^{e}$ pACT2 is compatible with pGBKT7 in TH assays

\section{Toxicity assay}

COS-7 cells were transfected with ${ }^{\mathrm{wt}} \mathrm{HSP} 22-\mathrm{CIT}[\underline{4}],{ }^{\mathrm{K} 141 \mathrm{E}} \mathrm{HSP} 22-$ CIT [ $\underline{6}]$, and ${ }^{\mathrm{K} 141 \mathrm{~N}} \mathrm{HSP} 22-\mathrm{CIT}[\underline{8}]$, or transfected with the "empty" CIT vector for control. Toxicity of the various HSP22-CFP species was evaluated after $24 \mathrm{~h}$ by determining the percentage of dead cells in each sample group using the Live/Dead Viability/Cytotoxicity kit (Invitrogen).

\section{Cross-linking}

HEK-293T cells were grown at $37^{\circ} \mathrm{C}$ in poly-L-lysine-pretreated 6-well plates in DMEM medium supplemented with $10 \%$ fetal calf serum in a $5 \% \mathrm{CO}_{2}$ humidified atmosphere. Cells were transfected at $\sim 80 \%$ confluency with $2 \mu \mathrm{g}$ of vector DNA of myc-tagged HSP22 species $[\underline{1}, \underline{2}, \underline{3}]$ using Lipofectamine 2000 (Invitrogen). $48 \mathrm{~h}$ later, cells were collected and washed three times with ice-cold PBS ( $\mathrm{pH} 8.0$ ). Cells were incubated with either 0.5 or $5 \mathrm{mM}$ of the homobifunctional amine-reactive cross-linker disuccinimidyl suberate (DSS; Pierce, Rockford, IL) for $30 \mathrm{~min}$ at room temperature. The reaction was stopped by adding Tris-HCl ( $\mathrm{pH} 7.5)$ to $15 \mathrm{mM}$ final concentration. Fifteen minutes later, 1 vol of sample buffer $(125 \mathrm{mM}$ Tris-HCl, pH 6.8; $4 \%$ SDS; $20 \%$ glycerol; $400 \mathrm{mM}$ dithiothreitol; $0.01 \%$ bromphenol blue) was added. After a brief sonication and boiling for $5 \mathrm{~min}$, the samples were analyzed by SDS-PAGE and Western blot analysis. A monoclonal antimyc primary antibody (Ab) (Sigma, St. Louis, MO) and a goat antimouse horseradish-coupled secondary Ab (Pierce) were used for immunodetection.

\section{Data and statistics}

Quantitative data are expressed as mean \pm SE. Unpaired Student's $t$ test was applied to compare results between sample groups. The number of counted cells for each value was at least 400 in Fig. $1 \boldsymbol{E}(4 \leq n \leq 7)$, and $\sim 300$ in the viability assay $(11 \leq n \leq 13)$. The number of cells analyzed by the qFRET method were at least 47 in Figs. $3 B, 6 B, 7 D(n \geq 47)$. Differences between groups were considered statistically significant if $P<0.05$.

\section{RESULTS}

\section{Intracellular localization of ${ }^{\mathrm{mu}} \mathrm{HSP} 22$ and formation of protein aggregates}

After transfection of mammalian cells with aggregateforming proteins, these structures form in the cytoplasm in a time-dependent process usually starting at multiple foci. These multifoci type aggregates are then transported along microtubules to finally form a pericentrosomal mass $(27,28)$. Coexpression of aggregate- 
forming mutant sHSPs with wild-type sHSPs can attenuate this aggregate formation (29). To estimate the aggregate-forming potency of the used ${ }^{\mathrm{mu}} \mathrm{HSP} 22-\mathrm{CIT}$ fusion proteins, and to relate it to the interaction data (see below), we determined the proportion of aggregate-containing cells when ${ }^{\mathrm{mu}} \mathrm{HSP} 22$ was expressed alone or together with ${ }^{\text {wt }} \mathrm{HSP} 22$, HSP20, $\alpha \mathrm{B}$-Cry, or ${ }^{\text {wt }} \mathrm{HSP} 27$ as CFP fusion proteins.

In control experiments CIT and CFP alone did not form aggregates when expressed in COS-7 cells. Representative cells with nearly even cytoplasmic distribution of CIT and CFP are shown in Fig. 1A. Similarly, the expression of any of the used constructs of HSP20-CFP [10], $\alpha$ B-Cry-CFP [11], and ${ }^{\mathrm{wt}} \mathrm{HSP} 27-\mathrm{CFP}$ [12] alone did not result in any significant aggregate formation (not shown). In contrast, $24 \mathrm{~h}$ after transfection,

A

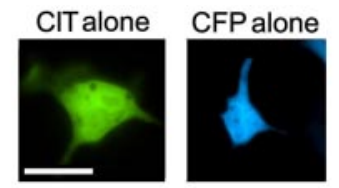

B

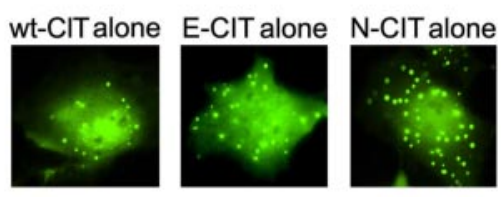

C

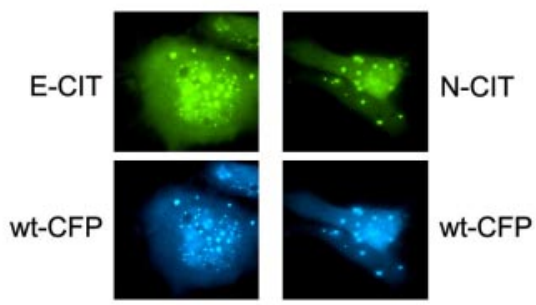

D

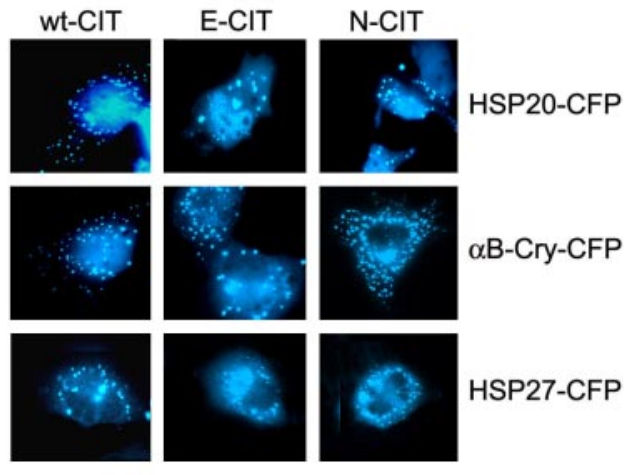

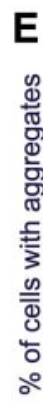

(CFP images only)

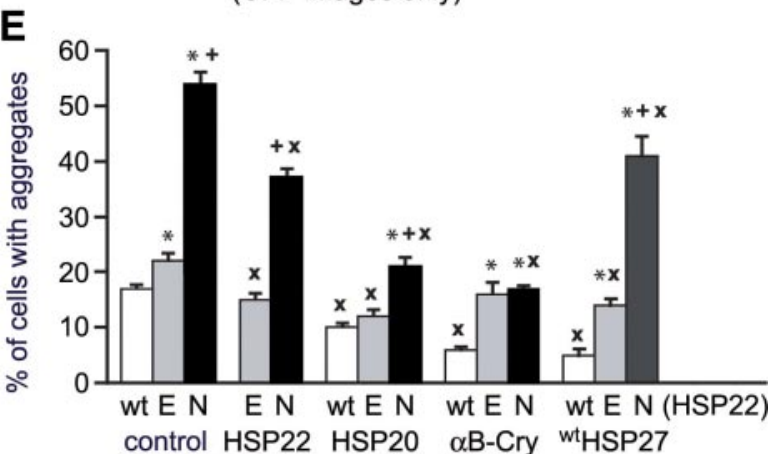

${ }^{\mathrm{wt}} \mathrm{HSP} 22-\mathrm{CIT}$ [4] , ${ }^{\mathrm{K} 141 \mathrm{E}} \mathrm{HSP} 22-\mathrm{CIT}$ [6], or ${ }^{\mathrm{K} 141 \mathrm{~N}} \mathrm{HSP} 22-$ CIT [ ] resulted in the formation of cytoplasmic multifoci type aggregates (Fig. $1 B$ ), although with a different incidence (see below). Coexpression of both forms of ${ }^{\mathrm{mu}}$ HSP22-CIT $[\underline{6}, \underline{8}]$ with ${ }^{\mathrm{wt}} \mathrm{HSP} 22-\mathrm{CFP}[\underline{5}]$ resulted in colocalization in the aggregates (Fig. 1C), while at the same time, the proportion of cells containing aggregates was decreased (see below). Similarly, coexpression of both ${ }^{\mathrm{mu} H S P 22-C I T}$ forms $[\underline{6}, \underline{8}]$ and of

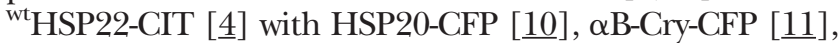

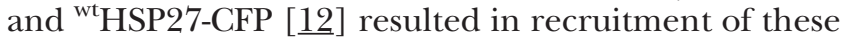
sHSPs into aggregates (Fig. 1D), as well as again lessening the proportion of cells containing aggregates (see below).

To quantify both the tendency of the mu HSP22 proteins to form aggregates and the ability of wild-type sHSPs to attenuate aggregate formation, the proportion of cells containing aggregates after transfection was calculated in these experiments. Expression of

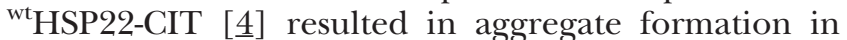
$\sim 17 \%$ of cells. This defined the baseline level for this construct in COS-7 cells (Fig. $1 E$, control group). Expression of ${ }^{\mathrm{K} 141 \mathrm{E}} \mathrm{HSP} 22-\mathrm{CIT}[\underline{6}]$ and ${ }^{\mathrm{K} 141 \mathrm{~N}} \mathrm{HSP} 22-\mathrm{CIT}$ [] resulted in a slightly and greatly increased aggregate formation affecting $\sim 21 \%$ and $54 \%$, respectively, of the transfected cells. Thus, both ${ }^{\mathrm{mu}} \mathrm{HSP} 22$ proteins have increased propensities to form aggregates, although to a different extent. Coexpression of wt HSP22CFP [ $\underline{5}$ ] with ${ }^{\mathrm{K} 141 \mathrm{E}} \mathrm{HSP} 22-\mathrm{CIT}$ [ㅁ] or with ${ }^{\mathrm{K} 141 \mathrm{~N}} \mathrm{HSP} 22-$ CIT [ $[$ ] significantly decreased aggregate formation to $\sim 15 \%$ and $37 \%$ (Fig. $1 E$, HSP22 group), respectively, as compared to expression of ${ }^{\mathrm{mu}} \mathrm{HSP} 22$ alone (Fig. $1 E$, control group).

To determine the effect of other sHSPs (HSP20, $\left.\alpha \mathrm{B}-\mathrm{Cry},{ }^{\mathrm{wt}} \mathrm{HSP} 27\right)$ on aggregate formation of ${ }^{\mathrm{wt}} \mathrm{HSP} 22$

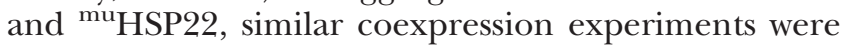
performed. In general, coexpression of HSP20-CFP [10],

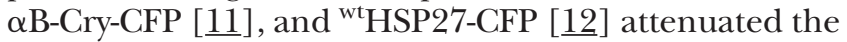
formation of aggregates that was caused by expression

Figure 1. Aggregate formation of ${ }^{\mathrm{wt}} \mathrm{HSP} 22$ and disease-associated ${ }^{\mathrm{mu}} \mathrm{HSP} 22$ in COS-7 cells. A) Representative images of control cells expressing CIT or CFP alone. B) Representative images of aggregate-containing cells expressing ${ }^{\text {wt }} \mathrm{HSP} 22-\mathrm{CIT}$

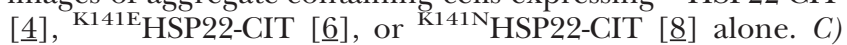
Representative images of aggregate-containing cells coexpressing ${ }^{\mathrm{K} 141 \mathrm{E}} \mathrm{HSP} 22-\mathrm{CIT} /{ }^{\mathrm{wt}} \mathrm{HSP} 22-\mathrm{CFP}[\underline{6} / \underline{5}]$ or ${ }^{\mathrm{K} 141 \mathrm{~N}} \mathrm{HSP} 22-$ $\mathrm{CIT} /{ }^{\mathrm{wt}} \mathrm{HSP} 22-\mathrm{CFP}[\underline{8} / \underline{\underline{5}}]$. D) Selected images of aggregate-containing cells coexpressing ${ }^{\text {wt }} \mathrm{HSP} 22-\mathrm{CIT}[\underline{4}],{ }^{\mathrm{K} 141 \mathrm{E}} \mathrm{HSP} 22-\mathrm{CIT}$ [ㅁ] , or K141N HSP22-CIT []] with HSP20-CFP [10], $\alpha \mathrm{B}-\mathrm{Cry}-$ CFP [11], or HSP27-CFP [12]. Only the CFP images are shown. E) Proportion of cells with aggregates $24 \mathrm{~h}$ after transfection. The usage of vectors was as in $B-D$. ${ }^{\text {wt } H S P 22,}$ ${ }_{\mathrm{K} 141 \mathrm{E}} \mathrm{HSP} 22$, or ${ }^{\mathrm{K} 141 \mathrm{~N}} \mathrm{HSP} 22$ were transfected alone (control group), or cotransfected with HSP20-CFP (HSP20 group), $\alpha \mathrm{B}-\mathrm{Cry}-\mathrm{CFP}$ ( $\alpha \mathrm{B}-\mathrm{Cry}$ group), or HSP27-CFP (HSP27 group). ${ }^{\mathrm{K} 141 \mathrm{E}}$ HSP22 and ${ }^{\mathrm{K} 141 \mathrm{~N}}$ HSP22 were also cotransfected with

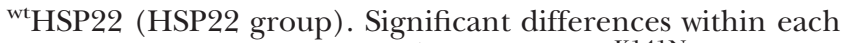
group (*, ${ }^{\mathrm{mu}} \mathrm{HSP} 22$ vs. ${ }^{\mathrm{wt}} \mathrm{HSP} 22 ; \quad+,{ }^{\mathrm{K} 141 \mathrm{~N} H S P 22}$ vs. $\left.{ }_{\mathrm{K} 141 \mathrm{E}} \mathrm{HSP} 22\right)$ and to the corresponding values of the control group $(\times)$ are indicated. The bar in $A$ indicates $50 \mu \mathrm{m}$. Abbreviations: wt, ${ }^{\text {wt } H S P 22 ; ~ E, ~}{ }^{\mathrm{K} 141 \mathrm{E}} \mathrm{HSP} 22$; N, ${ }^{\mathrm{K} 141 \mathrm{~N}} \mathrm{HSP} 22$. 
of either ${ }^{\mathrm{wt}} \mathrm{HSP} 22-\mathrm{CIT}$ [4], ${ }^{\mathrm{K} 141 \mathrm{E}} \mathrm{HSP} 22-\mathrm{CIT}$ [6] , or ${ }_{\mathrm{K} 141 \mathrm{~N}} \mathrm{HSP} 22-\mathrm{CIT}$ [ㅇ] (Fig. 1E; HSP20, $\alpha \mathrm{B}$-Cry, and HSP27 groups), as compared to the expression of the corresponding HSP22 species alone (Fig. 1E; control group). However, the obtained patterns were different for each of the tested sHSPs. For example, aggregate formation by ${ }^{\mathrm{K} 141 \mathrm{~N}} \mathrm{HSP} 22-\mathrm{CIT}$ was more effectively attenuated by HSP20 or $\alpha \mathrm{B}$-Cry than by ${ }^{\mathrm{wt}} \mathrm{HSP} 27$, whereas

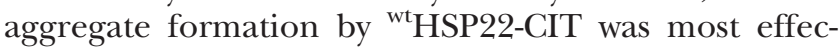
tively attenuated by $\alpha \mathrm{B}$-Cry or ${ }^{\mathrm{wt}} \mathrm{HSP} 27$.

It has been reported that ectopic expression of both forms of ${ }^{\mathrm{mu}}$ HSP22 in N2a neuronal cells reduced cell viability significantly $48 \mathrm{~h}$ after transfection (6). Aggregate formation frequently correlates with reduced cell viability and disease, although mature aggregates may be relatively benign or even protective as compared to early prefibrillar aggregates (20). In the context of our study, reduced cell viability due to the possible toxicity of the various HSP22 species could interfere with the data presented in Fig. $1 E$. For that reason we evaluated the toxicity of ${ }^{\mathrm{wt}} \mathrm{HSP} 22-\mathrm{CIT}[\underline{4}]$ and ${ }^{\mathrm{mu}} \mathrm{HSP} 22-\mathrm{CIT}$ [ $\underline{6}$, 8] constructs by determining the proportion of dead cells using the Live/Dead Viability/Cytotoxicity kit. Twenty four hours after transfection with ${ }^{\text {wt HSP22-CIT, }}$ ${ }^{\mathrm{K} 141 \mathrm{E}} \mathrm{HSP} 22-\mathrm{CIT}$, or ${ }^{\mathrm{K} 141 \mathrm{~N}} \mathrm{HSP} 22-\mathrm{CIT}$, the proportion of dead cells $( \pm \mathrm{SE})$ was $3.27 \% \pm 0.52,4.44 \% \pm 0.65$, or $3.31 \pm 0.40$, respectively, as compared with $3.08 \% \pm$ 0.57 dead cells in control cells transfected with the "empty" CIT vector (all differences were statistically not significant). Thus, none of the constructs caused a significant decrease in the viability of the COS-7 cells $24 \mathrm{~h}$ after transfection.

Collectively, these data indicate that both ${ }^{\mathrm{mu}} \mathrm{HSP} 22$ proteins have an increased tendency to form aggregates, and wild-type sHSPs can attenuate this aggregate formation. Both ${ }^{\mathrm{mu}} \mathrm{HSP} 22$ proteins differ in their aggregate formation tendency and in their responsiveness to attenuation by ${ }^{\mathrm{wt}} \mathrm{HSP} 22$ and other wild-type sHSPs, thus indicating different properties between the two ${ }^{\mathrm{mu}}$ HSP22 forms.

Additionally, these data demonstrate that in all settings, a significant proportion of cells is not affected by aggregate formation $24 \mathrm{~h}$ after transfection. In these cells, the sHSPs show a relatively even distribution in the cytoplasm ( $c f$. Figs. 3A, 6A, 7C). Such cells were selected for qFRET measurements as described below.

\section{Interactions of ${ }^{\mathrm{mu}} \mathrm{HSP} 22$ with itself and with ${ }^{\mathrm{wt}} \mathrm{HSP} 22$}

We have determined the ability of both ${ }^{\mathrm{mu}} \mathrm{HSP} 22$ forms to interact with themselves and with ${ }^{\text {wt }} \mathrm{HSP} 22$. The ${ }^{\text {wt }} \mathrm{HSP} 22$ /

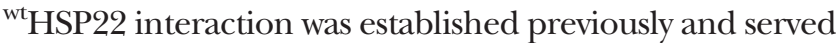
as a control (13). The TH experiments indicated activation of both reporter genes in the interactions ${ }^{\mathrm{K} 141 \mathrm{E}} \mathrm{HSP} 22 /{ }^{\mathrm{wt}} \mathrm{HSP} 22[\underline{16} / \underline{13}]$ and ${ }^{\mathrm{K} 141 \mathrm{~N}} \mathrm{HSP} 22 /{ }^{\mathrm{wt}} \mathrm{HSP} 22$ [18/13] (Fig. 2A). Similarly, the reporter genes were activated in the interactions ${ }^{\mathrm{K} 141 \mathrm{E}} \mathrm{HSP} 22 /{ }^{\mathrm{K} 141 \mathrm{E}} \mathrm{HSP} 22$ [15/16] and ${ }^{\mathrm{K} 141 \mathrm{~N}} \mathrm{HSP} 22 /{ }^{\mathrm{K} 141 \mathrm{~N}} \mathrm{HSP} 22$ [17/18]. Thus, all HSP22 species interacted with one another. Within the limits of this method, no differences in the inter-
A

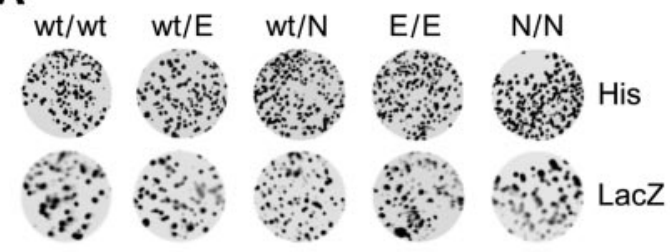

B

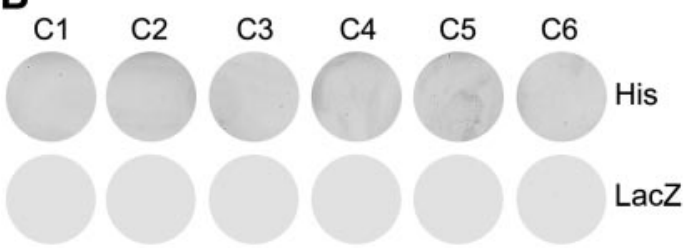

Figure 2. TH assays of the interactions of muHSP22 with ${ }^{\text {wt HSP22 }}$ and with themselves. A) Assays to determine the interactions of ${ }^{\mathrm{K} 141 \mathrm{E}} \mathrm{HSP} 22$ [15] with ${ }^{\text {wt }} \mathrm{HSP} 22$ [14] and with itself [16], and of ${ }^{\mathrm{K} 141 \mathrm{~N}} \mathrm{HSP} 22$ [17] with ${ }^{\mathrm{wt}} \mathrm{HSP} 22$ [14] and

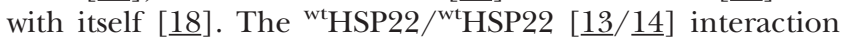
served as positive control. B) Negative TH controls: C1, C2,

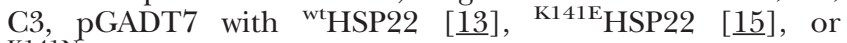
K141N HSP22 [17], respectively; C4, C5, C6, pGBKT7 with ${ }^{\mathrm{wt}} \mathrm{HSP} 22$ [14], ${ }^{\mathrm{K} 141 \mathrm{E}} \mathrm{HSP} 22$ [16], or ${ }^{\mathrm{K} 141 \mathrm{~N}} \mathrm{HSP} 22$ [18], respectively. Reporter genes: His (growth), LacZ (blue color). Abbreviations are as in Fig. 1.

action intensities were observed as compared to the

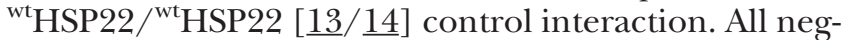
ative TH controls (C1-C6) were negative, thus rendering false-positive results unlikely (Fig. 2B).

For the qFRET analysis, COS-7 cells were transfected with various vector pairs to be analyzed. Twenty-four hours later, cells without aggregates and with even cytoplasmic distribution of the expressed proteins were selected. Representative cell images for all analyzed HSP22 pairs are shown in Fig. 3A. The AAFE values obtained for all tested interactions were significantly different from the negative control, thus indicating interaction (Fig. 3B). The AAFE for the ${ }^{\mathrm{K} 141 \mathrm{E}} \mathrm{HSP} 22$ / ${ }^{\text {wt HSP22 }}[\underline{7} / \underline{4}]$ interaction was similar to that of the ${ }^{\mathrm{wt}} \mathrm{HSP} 22 /{ }^{\mathrm{wt}} \mathrm{HSP} 22[\underline{4} / \underline{5}]$ interaction, while the AAFE for the ${ }^{\mathrm{K} 141 \mathrm{E}} \mathrm{HSP} 22 /{ }^{\mathrm{K} 141 \mathrm{E}} \mathrm{HSP} 22$ [ㅇ/ $\left./ \underline{7}\right]$ interaction was moderately, though significantly, increased as compared to that of the ${ }^{\mathrm{wt}} \mathrm{HSP} 22 /{ }^{\mathrm{wt}} \mathrm{HSP} 22[\underline{4} / \underline{5}]$ interaction. In contrast, ${ }^{\mathrm{K} 141 \mathrm{~N}} \mathrm{HSP} 22$ [9] showed a strongly (approximately two-fold) increased AAFE in the interactions with both ${ }^{\text {wt }} \mathrm{HSP} 22$ [4] and with itself []ㅡ, as compared to the ${ }^{\mathrm{wt}} \mathrm{HSP} 22 /{ }^{\mathrm{wt}} \mathrm{HSP} 22[\underline{4} / \underline{5}]$ interaction.

We used cross-linking (CL) as another approach to determine homodimer formation of the various HSP22 species. Additionally, this method can provide information on the formation of oligomers larger than dimers. HEK-293T cells were transfected with vectors to express myc-tagged ${ }^{\mathrm{wt}} \mathrm{HSP} 22$ [1], ${ }^{\mathrm{K} 141 \mathrm{E}} \mathrm{HSP} 22$ [2] , or

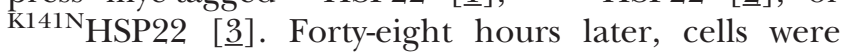
harvested, washed with PBS, and treated with $0.5 \mathrm{mM}$ or $5 \mathrm{mM}$ DSS, a homobifunctional cross-linker. The crosslinked proteins were then processed for SDS-PAGE, and Western blot analysis was performed using a mycspecific Ab detection system (Fig. 4). CL of ${ }^{\mathrm{wt}} \mathrm{HSP} 22$, 
A

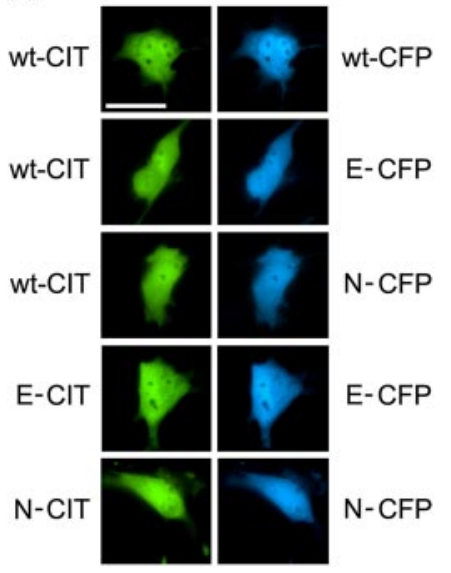

B

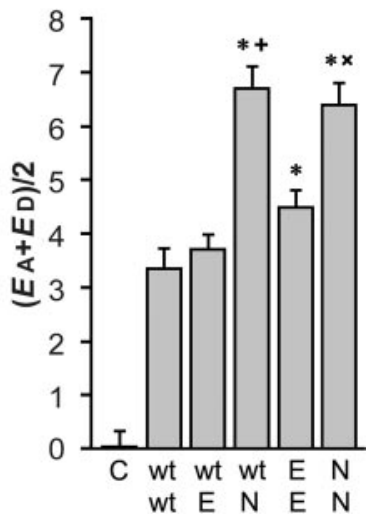

Figure 3. qFRET measurements of the interactions of ${ }^{\mathrm{mu}} \mathrm{HSP} 22$ forms with ${ }^{\mathrm{wt}} \mathrm{HSP} 22$ and with themselves. A) Representative images of doubly transfected COS-7 cells without aggregates coexpressing ${ }^{\mathrm{wt}} \mathrm{HSP} 22 /{ }^{\mathrm{wt}} \mathrm{HSP} 22[\underline{4} / \underline{5}],{ }^{\mathrm{wt}} \mathrm{HSP} 22 /$ ${ }_{\mathrm{K} 141 \mathrm{E}} \mathrm{HSP} 22$ [ $\left.\underline{4} / \underline{7}\right],{ }^{\mathrm{wt}} \mathrm{HSP} 22 /{ }^{\mathrm{K} 141 \mathrm{~N}} \mathrm{HSP} 22[\underline{4} / \underline{9}],{ }^{\mathrm{K} 141 \mathrm{E}} \mathrm{HSP} 22 /$ ${ }^{\mathrm{K} 141 \mathrm{E}} \mathrm{HSP} 22$ [6/7], or ${ }^{\mathrm{K} 141 \mathrm{~N}} \mathrm{HSP} 22 /{ }^{\mathrm{K} 141 \mathrm{~N}} \mathrm{HSP} 22$ [8/9] as CIT and CFP fusion proteins as indicated. The bar indicates 50 $\mu \mathrm{m}$. B) AAFE as determined by the qFRET method in doubly transfected COS-7 cells expressing the various HSP22 species, as indicated. The measured interactions, and the constructs used were as in $A$. All sample values were significantly different from the control. Significant differences from the ${ }^{\mathrm{wt}} \mathrm{HSP} 22 /{ }^{\mathrm{wt}} \mathrm{HSP} 22$ interaction (*), from the ${ }^{\mathrm{wt}} \mathrm{HSP} 22 /$ ${ }^{\mathrm{K} 141 \mathrm{E}} \mathrm{HSP} 22$ interaction $(+)$, and from the ${ }^{\mathrm{K} 141 \mathrm{E}} \mathrm{HSP} 22$ / ${ }^{\mathrm{K} 141 \mathrm{E}} \mathrm{HSP} 22$ interaction $(X)$ are indicated where appropriate. Abbreviations: $\mathrm{C}$, control; other abbreviations are as in Fig. 1.

${ }^{\mathrm{K} 141 \mathrm{E}} \mathrm{HSP} 22$, or ${ }^{\mathrm{K} 141 \mathrm{~N}} \mathrm{HSP} 22$ with $0.5 \mathrm{mM}$ or $5 \mathrm{mM}$ DSS provided one major band each in the dimer region. CL with $5 \mathrm{mM}$ DSS resulted in additional bands at the position of possibly tetramers, similar to earlier observations (13). No major differences in the intensities of the bands between ${ }^{\text {wt }} \mathrm{HSP} 22$ and ${ }^{\mathrm{mu}} \mathrm{HSP} 22$ were observed. The controls were 1) nontransfected and noncross-linked cells; 2) nontransfected and cross-linked cells (0.5 and $5 \mathrm{mM}$ DSS); and 3) transfected ( ${ }^{\mathrm{wt}} \mathrm{HSP} 22$, $\left.{ }^{\mathrm{K} 141 \mathrm{E}} \mathrm{HSP} 22,{ }^{\mathrm{K} 141 \mathrm{~N}} \mathrm{HSP} 22\right)$ and noncross-linked cells, as indicated. Only in transfected cells was myc-HSP22 detected (either as monomers, dimers, or tetramers). No dimer or tetramer bands of myc-HSP22 were detected in any of the control cells. The endogenous myc protein was detected in all cells (position indicated) and did not interfere with the assays.

Collectively, the TH, qFRET, and CL data suggest that the ${ }^{\mathrm{mu}} \mathrm{HSP} 22$ proteins interact with themselves and

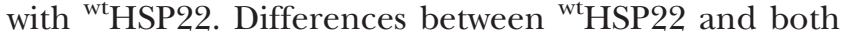
${ }^{\mathrm{mu}} \mathrm{HSP} 22$ forms could be demonstrated by the qFRET method due to its greater sensitivity. At the dimer level, ${ }^{\mathrm{K} 141 \mathrm{~N}} \mathrm{HSP} 22$ had an increased interaction with ${ }^{\mathrm{wt}} \mathrm{HSP} 22$, and both ${ }^{\mathrm{mu}} \mathrm{HSP} 22$ proteins demonstrated increased interaction with themselves, as compared to ${ }^{\mathrm{wt}} \mathrm{HSP} 22$ interacting with itself. The interaction properties of ${ }^{\mathrm{K} 141 \mathrm{~N}}$ HSP22 were more deviating from ${ }^{\text {wt }} \mathrm{HSP} 22$ than those of ${ }^{\mathrm{K} 141 \mathrm{E}} \mathrm{HSP} 22$. The CL data suggest that both ${ }^{\mathrm{mu}} \mathrm{HSP} 22$ forms had an ability similar to ${ }^{\mathrm{wt}} \mathrm{HSP} 22$ to form homotetramers.

\section{Interactions of ${ }^{\mathrm{mu}} \mathrm{HSP} 22$ with HSP20, $\alpha \mathrm{B}-\mathrm{Cry}$, and ${ }^{\text {wt }} \mathrm{HSP27}$}

Previously it was shown that ${ }^{\mathrm{wt}} \mathrm{HSP} 22$ interacts with HSP20, $\alpha$ B-Cry, and ${ }^{\text {wt HSP27 }}(12,13)$. To determine potentially abnormal interaction properties with these sHSPs, both ${ }^{\mathrm{mu}} \mathrm{HSP} 22$ forms were probed in TH and qFRET assays.

The TH data suggested that both ${ }^{\mathrm{K} 141 \mathrm{E}} \mathrm{HSP} 22$ [15] and ${ }^{\mathrm{K} 141 \mathrm{~N}} \mathrm{HSP} 22$ [17] interact with HSP20 [무], $\alpha \mathrm{B}$-Cry [21], and ${ }^{\mathrm{wt}} \mathrm{HSP} 27$ [19], in a manner similar to ${ }^{\mathrm{wt}} \mathrm{HSP} 22$ [13] (Fig. 5A). Within the limits of this method, no differences in the interaction stoichiometry between ${ }^{\mathrm{mu} H S P} 22$ and ${ }^{\mathrm{wt}} \mathrm{HSP} 22$ were observed. All negative TH controls (C7-C12) provided negative results, as expected (Fig. $5 B$ ).

The qFRET analysis in doubly transfected cells was performed as described above. In contrast to HSP22CIT fusion proteins, which are located in both the cytoplasm and the nuclei, the fusion proteins HSP20-

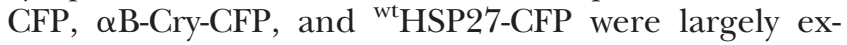
cluded from nuclei. Representative CFP images of cells coexpressing these three sHSP-CFP fusion proteins together with the various forms of HSP22 are shown in Fig. 6A. The AAFE values for ${ }^{\mathrm{K} 141 \mathrm{E}} \mathrm{HSP} 22$ [ $[\underline{6}]$ or ${ }^{\mathrm{K} 141 \mathrm{~N}} \mathrm{HSP} 22[\underline{8}]$ with HSP20 [1ㅜ] as interacting partner were not significantly different from that of ${ }^{\text {wt }} \mathrm{HSP} 22$ [4], suggesting that the mutations do not affect this interaction (Fig. 6B, HSP20 group). In contrast, the AAFE values for ${ }^{\mathrm{K} 141 \mathrm{E}} \mathrm{HSP} 22$ [ㅁ] or ${ }^{\mathrm{K} 141 \mathrm{~N}} \mathrm{HSP} 22$ [ㅁ] with $\alpha \mathrm{B}-\mathrm{Cry}[11]$ as interacting partner were moderately, although significantly, increased ( $\alpha$ B-Cry group) as compared with ${ }^{\text {wt }} \mathrm{HSP} 22$ [4], suggesting that this
Figure 4. CL of ${ }^{\mathrm{wt}} \mathrm{HSP} 22$ and ${ }^{\mathrm{mu}} \mathrm{HSP} 22$ in HEK293T cells. Cells were transfected with myc-tagged

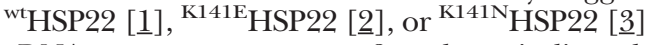
cDNAs, or were not transfected, as indicated. Forty-eight hours later, cell proteins were crosslinked with $0.5 \mathrm{mM}$ or $5 \mathrm{mM}$ DSS, or were left untreated. After CL, cells were harvested and processed for SDS-PAGE/Western blot analysis using a myc-specific Ab. Scale on the left: positions of molecular mass marker proteins. Scale on the right: positions of HSP22 monomers (1), HSP22 dimers (2), possibly HSP22 tetramers (4), and of the endogenous myc protein (myc).

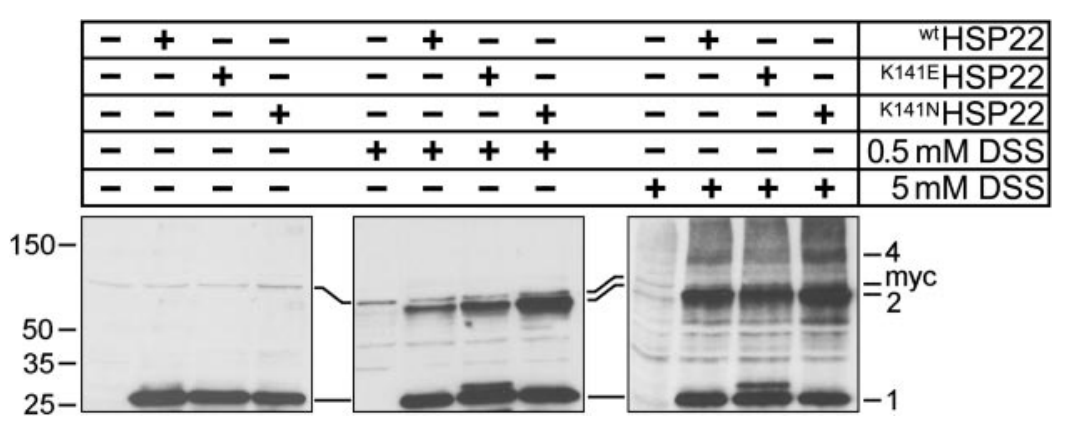



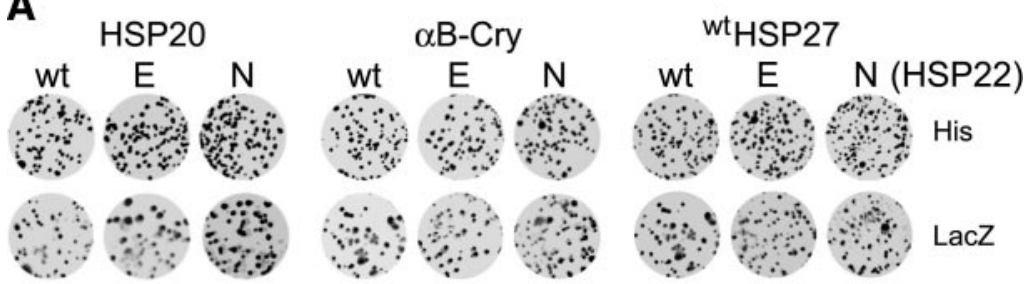

Figure 5. TH assays of the interactions of ${ }^{m}$ HSP22 with other sHSPs. A) Assays to determine the interactions of ${ }^{\mathrm{K} 141 \mathrm{E}} \mathrm{HSP} 22$ [15] and ${ }^{\mathrm{K} 141 \mathrm{~N}} \mathrm{HSP} 22$ [17] with HSP20 [이 ], $\alpha \mathrm{B}-\mathrm{Cry}[\underline{21}]$,

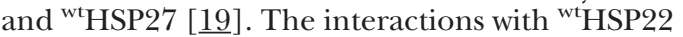
[13] served as positive controls. B) Negative TH

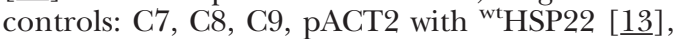
${ }^{\mathrm{K} 141 \mathrm{E}} \mathrm{HSP} 22$ [15] or ${ }^{\mathrm{K} 141 \mathrm{~N}} \mathrm{HSP} 22$ [17], respectively; C10, C11, C12, pGBKT7 with HSP20 [20], $\alpha$ B-Cry [21], or HSP27 [19], respectively. Reporter gene designation and abbreviations are as in Fig. 2.

LacZ

interaction is affected by both mutations. The AAFE values for both ${ }^{\mathrm{mu}} \mathrm{HSP} 22$ proteins were similar when compared to each other. Finally, the AAFE values for ${ }^{\mathrm{K} 141 \mathrm{E}} \mathrm{HSP} 22$ [ㅁ] and ${ }^{\mathrm{K} 141 \mathrm{~N}} \mathrm{HSP} 22$ [ㅁ] were moderately and strongly, respectively, increased with ${ }^{\text {wt HSP27 [12] }}$ as interacting partner (HSP27 group), as compared
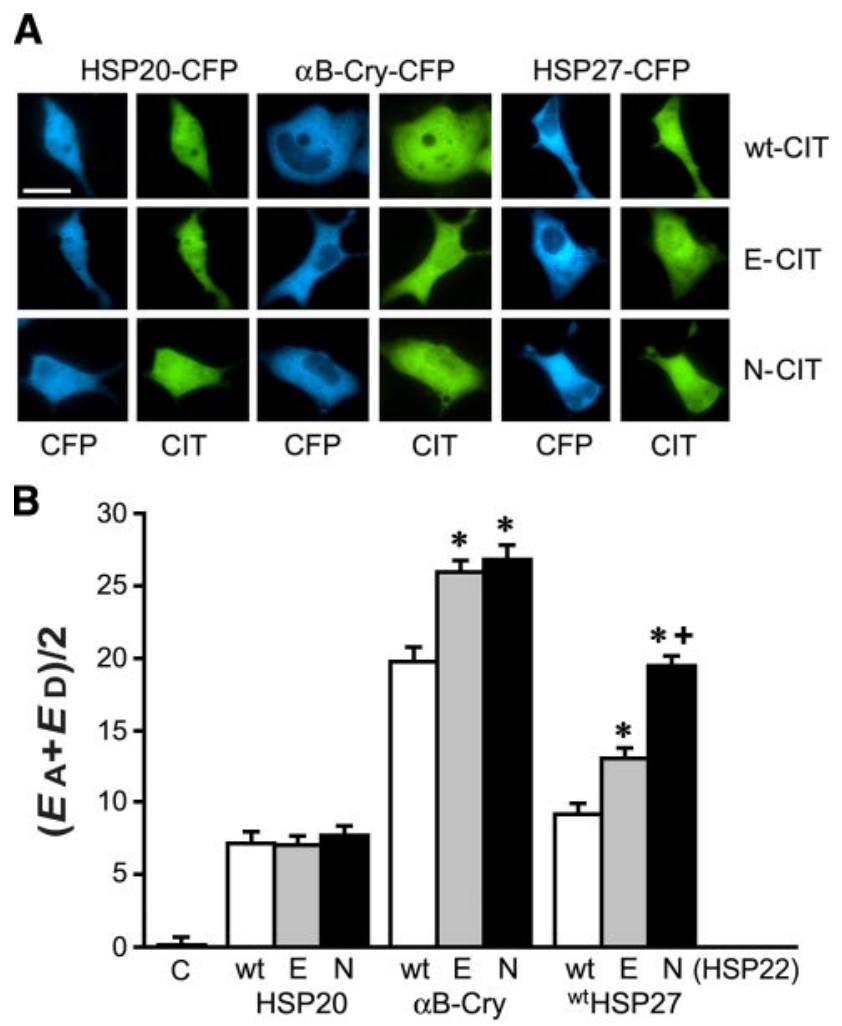

Figure 6. qFRET measurements of the interactions of ${ }^{\text {muSP22 }}$ with other sHSPs. A) Representative images of doubly-transfected COS-7 cells without aggregates coexpressing ${ }^{\mathrm{wt}} \mathrm{HSP} 22$ [4],${ }^{\mathrm{K} 141 \mathrm{E}} \mathrm{HSP} 22[\underline{6}]$, or ${ }^{\mathrm{K} 141 \mathrm{~N}} \mathrm{HSP} 22$ [] $]$ with HSP20 [10], $\alpha$ B-Cry [11], or HSP27 [12] as CIT and CFP fusion proteins as indicated. The bar indicates $50 \mu \mathrm{m} . B$ ) AAFE as determined by the qFRET method in doubly transfected COS-7 cells. The measured interactions of ${ }^{\mathrm{wt}} \mathrm{HSP} 22$, ${ }^{\mathrm{K} 141 \mathrm{E}} \mathrm{HSP} 22$, or ${ }^{\mathrm{K} 141 \mathrm{~N}} \mathrm{HSP} 22$ with the other sHSPs and the constructs used were as in $A$. All sample values were significantly different from the control. Significant differences within each group (*, ${ }^{\mathrm{mu}} \mathrm{HSP} 22$ vs. ${ }^{\mathrm{wt}} \mathrm{HSP} 22 ;+,{ }^{\mathrm{K} 141 \mathrm{~N}} \mathrm{HSP} 22$ vs. ${ }^{\mathrm{K} 141 \mathrm{E}}$ HSP22) are indicated. Abbreviations are as in Fig. 3. with ${ }^{\mathrm{wt}} \mathrm{HSP} 22$ [4]. Thus, both mutations result in increased interaction with ${ }^{\text {wt } H S P 27, ~ a l t h o u g h ~ t o ~ a ~ d i f f e r-~}$ ent extent.

Taken together, these data suggest that both ${ }^{\mathrm{mu}} \mathrm{HSP} 22$ proteins interact with HSP20, $\alpha \mathrm{B}-\mathrm{Cry}$, and

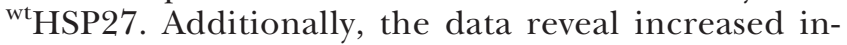
teractions of both ${ }^{\mathrm{mu}} \mathrm{HSP} 22$ proteins with $\alpha \mathrm{B}$-Cry and

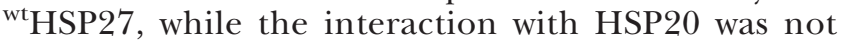
affected.

Because of the possibility that mutations in HSP27 affect the HSP22/HSP27 interaction in a similar way, we examined interaction properties of ${ }^{\mathrm{S} 135 \mathrm{~F}} \mathrm{HSP} 27$, one of the ${ }^{\mathrm{mu}} \mathrm{HSP} 27$ forms, which is associated with both dHMN type II and CMT type 2F (14). The TH data show that ${ }^{\mathrm{S} 135 \mathrm{~F}}$ HSP27 [23] or ${ }^{\mathrm{wt}} \mathrm{HSP} 27$ [22] interact

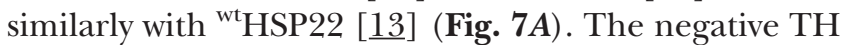
controls (C7, C13, C14) provided, as expected, negative results (Fig. 5B, 7B). For the qFRET analysis, COS-7 cells were doubly transfected to express ${ }^{\mathrm{S} 135 \mathrm{~F}} \mathrm{HSP} 27-$ CIT [25] or ${ }^{\mathrm{wt}} \mathrm{HSP} 27-\mathrm{CIT}$ [24], together with ${ }^{\mathrm{wt}} \mathrm{HSP} 22-$ CFP [ $\underline{5}]$. Representative cells with almost even cytoplasmic distribution of these fusion proteins are shown in Fig. $7 C$. The AAFE values obtained for the interactions of ${ }^{\mathrm{S} 135 \mathrm{~F}}$ HSP27 or ${ }^{\mathrm{wt}} \mathrm{HSP} 27$ with ${ }^{\mathrm{wt}} \mathrm{HSP} 22$ were significantly different from the negative control, thus indicating interaction (Fig. 7D). The AAFE for the ${ }^{\mathrm{S} 135 \mathrm{~F}}$ HSP27/ $/{ }^{\mathrm{wt}} \mathrm{HSP} 22$ interaction was significantly

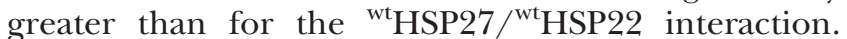
Thus, this ${ }^{\mathrm{mu}} \mathrm{HSP} 27$ form affects the HSP22/HSP27 interaction in a way similar to the two ${ }^{\mathrm{mu}} \mathrm{HSP} 22$ forms.

\section{DISCUSSION}

In the inherited disorders dHMN and CMT, the known affected genes are involved in very different cellular functions and pathways, including RNA processing and metabolism (glycyl-tRNA synthetase, senataxin, immunoglobin $\mu$-binding protein2), cytoskeletal functions (dynactin, KIF1B, neurofilament L protein), and others, thus illustrating the remarkable genetic heterogeneity that underlies these diseases. An additional group of affected genes is formed by the sHSPs (2-5). To date, it is not clear how mutations in these seemingly unrelated genes cause similar or even identical disease phenotypes. 
Figure 7. Interaction of ${ }^{\mathrm{S} 135 \mathrm{~F}} \mathrm{HSP} 27$ with ${ }^{\mathrm{wt}} \mathrm{HSP} 22$. A) $\mathrm{TH}$ assay to determine the interaction of ${ }^{\mathrm{S} 135 \mathrm{~F}} \mathrm{HSP} 27$

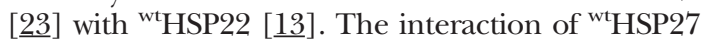
[22] with ${ }^{\mathrm{wt}} \mathrm{HSP} 22$ [13] served as positive control. B) Negative TH controls: C7 (cf. Fig 5); C13, C14,

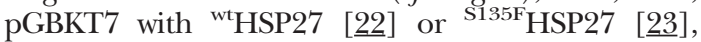
respectively. $C$ ) Representative images of doubly transfected COS-7 cells without aggregates co-expressing ${ }^{\mathrm{S} 135 \mathrm{~F}} \mathrm{HSP} 27$ [25] and ${ }^{\mathrm{wt}} \mathrm{HSP} 22$ [무], or ${ }^{\mathrm{wt}} \mathrm{HSP} 27$ [24] and ${ }^{\mathrm{wt}} \mathrm{HSP} 22[\underline{5}]$ as CIT and CFP fusion proteins as indicated. The bar indicates $50 \mu \mathrm{m}$. D) AAFE as determined by the qFRET method in doubly transfected COS-7 cells. The measured interactions of

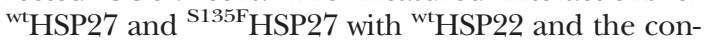
structs used were as in $C$. Both sample values were significantly different from the control. The significant difference between the ${ }^{\mathrm{S} 135 \mathrm{~F}} \mathrm{HSP} 27 /{ }^{\mathrm{wt}} \mathrm{HSP} 22$ interaction vs. the ${ }^{\mathrm{wt}} \mathrm{HSP} 27 /{ }^{\mathrm{wt}} \mathrm{HSP} 22$ interaction is indicated (*). Reporter gene designation in $A$ and $B$ is as in Fig. 2. Abbreviations: F, ${ }^{\mathrm{S} 135 \mathrm{~F}} \mathrm{HSP} 27$; other

A

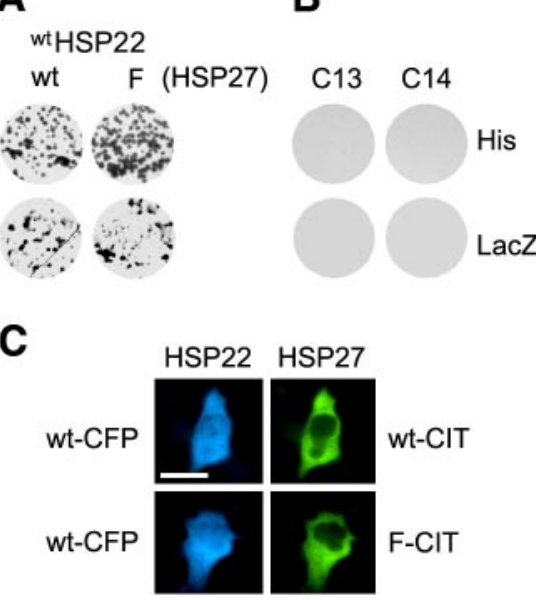

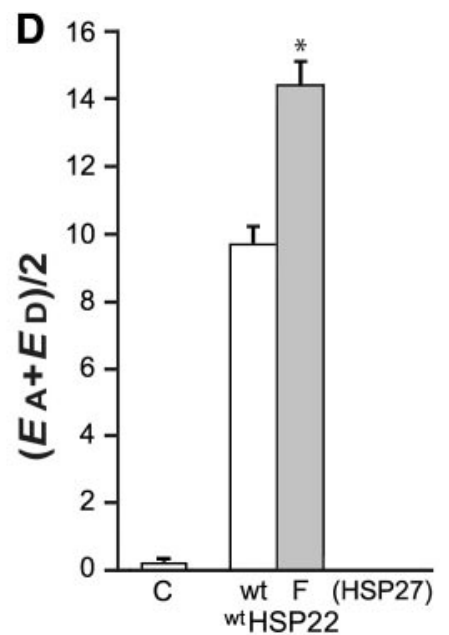
abbreviations are as in Fig. 3.

All of the currently eight known mutations in HSP22 and HSP27 are associated with the neuropathies dHMN type II and CMT type $2(6,7,14-16)$. In contrast, the currently four known mutations in $\alpha \mathrm{B}$-Cry, other than those which affect exclusively the lens of the eye, are associated with the myopathies desmin-related (myofibrillar) myopathy and dilated cardiomyopathy (17-19). Thus, although $\alpha$ B-Cry does interact with both HSP22 and HSP27 $(11,12,30)$, mutations in this protein have somewhat different pathological consequences. This may indicate a different functional role for $\alpha \mathrm{B}$-Cry, as compared to HSP22 and HSP27, or alternatively, it simply may reflect the high abundance of $\alpha \mathrm{B}$-Cry in heart and skeletal muscle tissues (31). Another remarkable observation is that all these mutations have dominant gain-of-function characteristics. The presence of the wild-type proteins in the diseased tissues does not prevent the manifestation of the diseases. A plausible explanation is that the insertion of only a few mutated protein molecules into heterooligomeric sHSP complexes results in the formation of malstructured and therefore malfunctioning sHSP complexes. Thus, the model, based on aberrant sHSP-sHSP interactions may provide the rationale for the genetic dominance, as is seen in these diseases. In the case of the neuropathies, the diseases show a late onset, indicating that the cell damage, due to malfunctioning sHSP complexes, accumulates over years before it becomes clinically manifest.

The data collected in this study show that both disease-associated forms of ${ }^{\mathrm{mu}} \mathrm{HSP} 22$ interact with

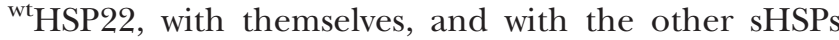
HSP20, $\alpha$ B-Cry and ${ }^{\mathrm{wt}} \mathrm{HSP} 27$. Some of the interactions involving ${ }^{\mathrm{mu}} \mathrm{HSP} 22$ exhibited increased stoichiometry, while others remained unchanged. None of the interactions was weakened. Each of the two ${ }^{\mathrm{mu}} \mathrm{HSP} 22$ forms had a characteristic pattern of abnormal interactions. A summary of the abnormal interactions as determined for ${ }^{\mathrm{K} 141 \mathrm{E}}$ HSP22 is given in Fig. $8 \boldsymbol{A}$ and that for ${ }^{\mathrm{K} 141 \mathrm{~N}} \mathrm{HSP} 22$ in Fig. $8 B$. The interaction characteristics of ${ }^{\mathrm{K} 141 \mathrm{~N}} \mathrm{HSP} 22$ deviated more from ${ }^{\mathrm{wt}} \mathrm{HSP} 22$ than the characteristics of ${ }^{\mathrm{K} 141 \mathrm{E}} \mathrm{HSP} 22$. Whether this correlates to the clinical phenotype, e.g., the severity of the associated diseases, remains to be determined.

We have investigated the interaction of one of the HSP27 mutants ( ${ }^{\mathrm{S} 135 \mathrm{~F}}$ HSP27) with HSP22 and found

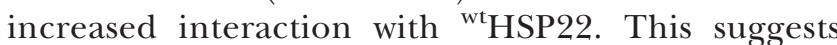
that mutations in either HSP22 or HSP27 may result in a similarly abnormal increase in the interaction between both proteins (Fig. 8C) and that this increased HSP22/HSP27 interaction then contributes to the manifestation of both motor neuron diseases. These data may reflect the existence of a relationship between the three etiologic factors ${ }^{\mathrm{K} 141 \mathrm{E}} \mathrm{HSP} 22$, ${ }^{\mathrm{K} 141 \mathrm{~N}} \mathrm{HSP} 22$, and ${ }^{\mathrm{S} 135 \mathrm{~F}} \mathrm{HSP} 27$ in one common pathway.

Although principally all proteins, depending on the conditions, are prone to aggregate formation, mutant proteins, in general, have a higher tendency to form aggregates (32). Therefore, it is not surprising that
Fig. 8 Schematic of identified abnormal interactions at the dimer level involving diseaseassociated ${ }^{\mathrm{K} 141 \mathrm{E}} \mathrm{HSP} 22,{ }^{\mathrm{K} 141 \mathrm{~N}} \mathrm{HSP} 22$, and ${ }^{\mathrm{S} 135 \mathrm{~F}} \mathrm{HSP} 27$. Single interactions were found unchanged (-), moderately increased (-), or greatly increased $(\boldsymbol{\omega})$ in comparison with the
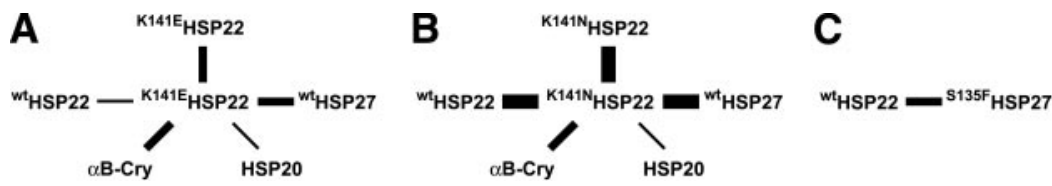
corresponding wild-type sHSPs in the same interaction. A) ${ }^{\mathrm{K} 141 \mathrm{E}} \mathrm{HSP} 22$ has moderately increased interactions with itself, $\alpha \mathrm{B}-\mathrm{Cry}$, and ${ }^{{ }^{w}}$ HSP27. B) ${ }^{\mathrm{K} 141 \mathrm{~N}}$ HSP22 has greatly increased interactions with itself, ${ }^{\mathrm{wt}} \mathrm{HSP} 22$, and ${ }^{\text {wt }} \mathrm{HSP} 27$, and moderately increased interaction with $\alpha \mathrm{B}-\mathrm{Cry}$. C) ${ }^{\mathrm{S} 135 \mathrm{~F}} \mathrm{HSP} 27$ has moderately increased interaction with ${ }^{\text {wt }} \mathrm{HSP} 22$. Note that each ${ }^{\mathrm{mu}} \mathrm{HSP} 22$ form has a characteristic, abnormal interaction pattern. That ${ }^{\mathrm{mu}} \mathrm{HSP} 22$ has increased interaction with ${ }^{\text {wt }} \mathrm{HSP} 27$ and that ${ }^{\mathrm{S} 135 \mathrm{~F}} \mathrm{HSP} 27 \mathrm{has}$ increased interaction with ${ }^{\text {wt HSP22 }}$ and mutations in HSP22 or HSP27 resulting in a similar disease suggest that both mutant proteins may act through the same mechanism. 
both mutant forms of HSP22 have an increased tendency to form aggregates (Fig. $1 E$ ), similarly as was reported previously (6). For three other sHSP mutants, including ${ }^{\mathrm{P} 182 \mathrm{~L}} \mathrm{HSP} 27$ (22), ${ }^{\mathrm{S} 135 \mathrm{~F}} \mathrm{HSP} 27$ (14), and ${ }_{\text {R120G }} \alpha$ B-Cry $(17,23)$, this has been also demonstrated. Although the ${ }^{\mathrm{R} 120 \mathrm{G}} \alpha \mathrm{B}$-Cry aggregates meet the criteria for true ameloid fibrils or aggresomes (23) usually seen in neurodegenerative diseases, this characteristic remains to be verified for the mutant HSP22 and HSP27 aggregates. Although protein aggregates frequently are associated with disease, their significance for cell viability is not clear. Aggregates may be cytotoxic, they may be inert, or they even may be the end product of a cellular "detoxifying" response (33). What seems clear is that large mass end products of the aggregation process are relatively benign as compared to the more toxic early prefibrillar aggregates. Cytotoxicity for both mutant forms of HSP22 in transfected neuronal cells has been demonstrated previously (6). The fact that we could not detect any cytotoxic effects of either mutant form of HSP22 in COS-7 cells may have its cause in the cell type used. More likely, however, is that $24 \mathrm{~h}$ after transfection, the toxicity of the aggregates, be it in the prefibrillar or in the fibrillar stage, has not yet developed, as it would several days after transfection. The fact that no cytotoxic effects distort the data, as shown in Fig. $1 E$, strengthens the conclusion that both mutant forms of HSP22 have an increased tendency to form aggregates as compared to ${ }^{\mathrm{wt}} \mathrm{HSP} 22$. This increased tendency of both ${ }^{\mathrm{mu}} \mathrm{HSP} 22$ proteins to form aggregates may well be caused by their abnormally increased ability to interact with ${ }^{\text {wt }} \mathrm{HSP} 22$ and with some of the other sHSPs.

In summary, the data presented here provide an initial rationale for the pathogenesis of the ${ }^{\mathrm{mu}} \mathrm{HSP} 22$ associated motor neuropathies dHMN and CMT. The precise mechanism by which the aberrant interaction and aggregate forming properties of ${ }^{\mathrm{mu}} \mathrm{HSP} 22$ translate into the slow death of neurons remains to be elucidated. FJ

We thank L.A. Weber (Reno, NV) and J. Horwitz (Los Angeles, CA) for providing us with HSP27 and $\alpha$ B-Cry cDNA, respectively. This work was supported by National Institutes of Health Grant P01ES11188 to M.J.W. (PI) and R.B., by a Munn Idea grant of the University of Michigan Comprehensive Cancer Center to R. Benndorf, by the French Ministry of Research and the Association Française contre les Myopathies (AFM) to S.S., and by the Centre National de la Recherche Scientifique (CNRS) and the AFM Grant 11764 to P.V.

\section{REFERENCES}

1. Harding, A. E., and Thomas, P. K. (1980) The clinical features of hereditary motor and sensory neuropathy types I and II. Brain. 103, 259-280

2. Irobi, J., De Jonghe, P., and Timmerman, V. (2004) Molecular genetics of distal hereditary motor neuropathies. Hum. Mol. Genet. 13, Suppl. 2, R195-R202

3. Shy, M. E. (2004) Charcot-Marie-Tooth disease: an update. Curr. Opin. Neurobiol. 17, 579-585

4. Benndorf, R., and Welsh, M. J. (2004) Shocking degeneration. Nat. Genet. 36, 547-548

5. Dierick, I., Irobi, J., De Jonghe, P., and Timmerman, V. (2005) Small heat shock proteins in inherited peripheral neuropathies. Ann. Med. 37, 413-422
6. Irobi, J., Impe, K.V., Seeman, P., Jordanova, A., Dierick, I., Verpoorten, N., Michalik, A., Vriendt, E.D., Jacobs, A., Gerwen, V.V., et al. (2004) Hot-spot residue in small heat-shock protein 22 causes distal motor neuropathy. Nat. Genet. 36, 597-601

7. Tang, B.S., Zhao, G.H., Luo, W., Xia, K., Cai, F., Pan, Q., Zhang, R.X., Zhang, F.F., Liu, X.M., Chen, B., et al. (2005) Small heat-shock protein 22 mutated in autosomal dominant CharcotMarie-Tooth disease type 2L. Hum. Genet. 116, 222-224

8. Verschuure, P., Tatard, C., Boelens, W.C., Grongnet, J. F., and David, J. C. (2003) Expression of small heat shock proteins HspB2, HspB8, Hsp20 and cvHsp in different tissues of the perinatal developing pig. Eur. J. Cell Biol. 82, 523-530

9. Ehrnsperger, M., Lilie, H., Gaestel, M., and Buchner, J. (1999) The dynamics of Hsp25 quaternary structure. Structure and function of different oligomeric species. J. Biol. Chem. 274, 14867-14874

10. Lelj-Garolla, B., and Mauk, A. G. (2005) Self-association of a small heat shock protein. J. Mol. Biol. 345, 631-642

11. Sugiyama, Y., Suzuki, A., Kishikawa, M., Akutsu, R., Hirose, T., Waye, M.M., Tsui, S.K.W., Yoshida, S., and Ohno, S. (2000) Muscle develops a specific form of small heat shock protein complex composed of MKBP/HSPB2 and HSPB3 during myogenic differentiation. J. Biol. Chem. 275, 1095-1104

12. Fontaine, J.-M., Sun, X., Benndorf, R., and Welsh, M. J. (2005) Interactions of HSP22 with HSP20, $\alpha$ B-crystallin, and HSPB3. Biochem. Biophys. Res. Commun. 337, 1006-1011

13. Sun, X., Fontaine, J.-M., Rest, J.S., Shelden, E.A., Welsh, M. J., and Benndorf, R. (2004) Interaction of human HSP22 (HSPB8) with other small heat shock proteins. J. Biol. Chem. 279, 23942402

14. Evgrafov, O.V., Mersiyanova, I., Irobi, J., van den Bosch, L., Dierick, I., Leung, C.L., Schagina O., Verpoorten, N., van Impe, K., Fedotov, V., et al. (2004) Mutant small heat-shock protein 27 causes axonal Charcot-Marie-Tooth disease and distal hereditary motor neuropathy. Nat. Genet. 36, 602-606

15. Kijima, K., Numakura, C., Goto T., Takahashi, T., Otagiri, T., Umetsu, K., Hayasaka, K. (2005) Small heat shock protein 27 mutation in a Japanese patient with distal hereditary motor neuropathy. J. Hum. Genet. 50, 473-476

16. Liu X.M., Tang, B.S., Zhao, G.H., Xia, K., Zhang, F.F., Pan, Q., Cai, F., Hu, Z.M., Zhang, C., Chen, B., et al. (2005) Mutation analysis of small heat shock protein 27 gene in Chinese patients with Charcot-Marie-Tooth disease. Zhonghua Yi Xue Yi Chuan Xue Za Zhi. 22, 510-513

17. Vicart, P., Caron, A., Guicheney, Li, P., Z., Prevost, M.C., Faure A., Chateau, D., Chapon, F., Tome, F., Dupret, J.M., Paulin, D., et al. (1998) A missense mutation in the alphaB-crystallin chaperone gene causes a desmin-related myopathy. Nat. Genet. 20, 92-95

18. Selcen, D., and Engel, A. G. (2003) Myofibrillar myopathy caused by novel dominant negative $\alpha \mathrm{B}$-crystallin mutations Ann. Neurol. 54, 804-810

19. Inagaki, N., Hayashi, T., Arimura, T., Koga, Y., Takahashi, M., Shibata, H., Teraoka, K., Chikamori, T., Yamashina, A., and Kimura, A. (2006) AlphaB-crystallin mutation in dilated cardiomyopathy. Biochem. Biophys. Res. Commun. 342, 379-386

20. Dobson, C. M. (2003) Protein folding and misfolding. Nature 426, 884-890

21. Lowe, J., Mayer, J., Landon, M., and Layfield, R. (2001) Ubiquitin and the molecular pathology of neurodegenerative diseases. Adv. Exp. Med. Biol. 487, 169-186

22. Ackerley, S., James, P.A., Kalli, A., French, S., Davies, K. E., and Talbot, K. (2006) A mutation in the small heat-shock protein HSPB1 leading to distal hereditary motor neuronopathy disrupts neurofilament assembly and the axonal transport of specific cellular cargoes. Hum. Mol. Genet. 15, 347-354

23. Sanbe, A., Osinska, H., Saffitz, J.E., Glabe, C.G., Kayed, R., Maloyan, A., and Robbins, J. (2004) Desmin-related cardiomyopathy in transgenic mice: a cardiac amyloidosis. Proc. Natl. Acad. Sci. U. S. A. 101, 10132-10136

24. Hoppe, A., Christensen, K., and Swanson, J. A. (2002) Fluorescence resonance energy transfer-based stoichiometry in living cells. Biophys. J. 83, 3652-3664

25. Sun, X., Welsh, M. J., and Benndorf, R. (2006) Conformational changes due to pseudophosphorylation of mammalian small heat shock proteins - a two hybrid study. Cell Stress Chaperones. 11, 61-70 
26. Hoppe, A., and Swanson, J. A. (2004) Cdc42, Rac1, and Rac2 display distinct patterns of activation during phagocytosis. Mol. Biol. Cell. 15, 3509-3519

27. Garcia-Mata, R., Bebok, Z., Sorscher, E. J., and Sztul, E. S. (1999) Characterization and dynamics of aggresome formation by a cytosolic GFP-chimera. J. Cell Biol. 146, 1239-1254

28. Wigley, W.C., Fabunmi, R.P., Lee, M.G., Marino, C.R., Muallem, S., DeMartino, G. N., and Thomas, P. J. (1999) Dynamic association of proteasomal machinery with the centrosome. J. Cell Biol. 145, 481-490

29. Chavez-Zobel, A. T., Loranger, A., Marceau, N., Theriault, J. R., Lambert, H., and Landry, J. (2003) Distinct chaperone mechanisms can delay the formation of aggresomes by the myopathycausing R120G alphaB-crystallin mutant. Hum. Mol. Genet. 12, 1609-1620

30. Liu, C., and Welsh, M. J. (1999) Identification of a site of HSP27 binding with HSP27 and $\alpha$ B-crystallin as indicated by the yeast two-hybrid system. Biochem. Biophys. Res. Commun. 255, 256-261

31. Inaguma, Y., Hasegawa, K., Goto, S., Ito, H., and Kato, K. (1995) Induction of the synthesis of hsp27 and alphaB-crystallin in tissues of heat-stressed rats and its suppression by ethanol or an alpha 1-adrenergic antagonist. J. Biochem. (Tokyo). 117, 12381243

32. Stefani, M., and Dobson, C. M. (2003) Protein aggregation and aggregate toxicity: new insights into protein folding, misfolding diseases and biological evolution.J. Mol. Med. 81, 678-699

33. Muchowski, P. J., and Wacker, J. L. (2005) Modulation of neurodegeneration by molecular chaperones. Nat. Rev. Neurosci. 6, 11-22

Received for publication February 9, 2006 Accepted for publication May 25, 2006. 


\title{
Abnormal small heat shock protein interactions involving neuropathy-associated HSP22 (HSPB8) mutants
}

\author{
Jean-Marc Fontaine, $*$ Xiankui Sun, ${ }^{*}$ Adam D. Hoppe, ${ }^{\dagger}$ Stephanie Simon, ${ }^{\ddagger}$ \\ Patrick Vicart, ${ }^{\ddagger}$ Michael J. Welsh, ${ }^{*}$ and Rainer Benndorf*,1 \\ Departments of *Cell and Developmental Biology, and ${ }^{\dagger}$ Microbiology and Immunology, University of \\ Michigan Medical School, Ann Arbor, Michigan, USA; and ${ }^{+}$EA 300 Stress et Pathologies du \\ Cytosquelette, Université Paris 7, UFR de Biochimie, Paris, France
}

To read the full text of this article, go to http://www.fasebj.org/cgi/doi/10.1096/fj.06-5911fje

\section{SPECIFIC AIMS}

Mutations in the small heat shock protein HSP22, ${ }^{\mathrm{K} 141 \mathrm{E}} \mathrm{HSP} 22$ and ${ }^{\mathrm{K} 141 \mathrm{~N}} \mathrm{HSP} 22$, cause motor neuron degeneration in the human diseases distal hereditary motor neuropathy (dHMN) type II and Charcot-MarieTooth disease (CMT) type 2L. Small heat shock proteins (sHSP) interact with one another, and our aim was to determine whether changes occurred in the interaction properties of both forms of mutant (mu) HSP22 with themselves, with wild-type (wt) HSP22, and with the other sHSPs HSP27, HSP20, and $\alpha$ B-crystallin ( $\alpha$ B-Cry), all of which are abundant in neurons.

\section{PRINCIPAL FINDINGS}

\section{Disease-associated ${ }^{\mathrm{mu}} \mathrm{HSP} 22$ has an increased} tendency to form intracellular protein aggregates

Mutant proteins, in general, have an increased tendency to form cytoplasmic protein aggregates. Formation of aggregates involving ${ }^{\mathrm{mu}} \mathrm{HSP} 22$ may result from aberrant interaction properties (see below), and it also may interfere with the applied methods to determine protein interactions. Therefore, the tendency of the two known ${ }^{\mathrm{mu} H S P} 22$ proteins to form aggregates was examined in transfected COS-7 cells by determining the proportion of cells containing protein aggregates. In these assays, fusion proteins were used consisting of the various sHSP species fused to derivatives of the green fluorescent protein, citrine (CIT), or cyan fluorescent protein (CFP). Twenty-four hours after transfection, the proportion of cells containing aggregates was quantified. Expression of ${ }^{\mathrm{K} 141 \mathrm{E}} \mathrm{HSP} 22-\mathrm{CIT}$ and ${ }_{\mathrm{K} 141 \mathrm{~N}} \mathrm{HSP} 22-\mathrm{CIT}$ resulted in a slight $(\sim 21 \%)$ and great $(\sim 54 \%)$, respectively, increase in the proportion of cells with aggregates, as compared to the ${ }^{\mathrm{wt}} \mathrm{HSP} 22-\mathrm{CIT}$ control $(\sim 17 \%)$, which defines the baseline level for this construct. Thus, both ${ }^{\mathrm{mu}} \mathrm{HSP} 22$ forms had, although to a different extent, an increased tendency to form aggregates as compared to ${ }^{\mathrm{wt}} \mathrm{HSP} 22$.
Mutant proteins can recruit wild-type proteins into aggregates, while wild-type proteins can attenuate aggregate formation by mutant proteins. To evaluate this mutual relationship, experiments were conducted in which both ${ }^{\mathrm{mu}} \mathrm{HSP} 22$ forms and, for control also, ${ }^{\mathrm{wt}} \mathrm{HSP} 22$ (all as CIT fusion proteins) were coexpressed with

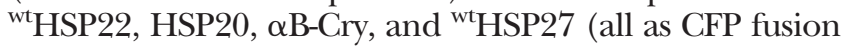
proteins). Both ${ }^{\mathrm{mu}} \mathrm{HSP} 22-\mathrm{CIT}$ forms and also ${ }^{\mathrm{wt}} \mathrm{HSP} 22-$ CIT were found to recruit all tested other sHSP-CFP proteins (HSP20, $\alpha$ B-Cry, $\left.{ }^{\text {wt } H S P 27, ~}{ }^{\mathrm{wt}} \mathrm{HSP} 22\right)$ into aggregates. These ${ }^{{ }^{\mathrm{w}} \mathrm{sHSP}}$ also significantly attenuated the formation of aggregates by both ${ }^{\mathrm{mu}} \mathrm{HSP} 22-\mathrm{CIT}$ and ${ }^{\text {wt} H S P 22-C I T . ~ H o w e v e r, ~ t h e ~ o b t a i n e d ~ p a t t e r n s ~ w e r e ~ d i f f e r-~}$ ent for each tested sHSP. For example, aggregate formation by ${ }^{\mathrm{K} 141 \mathrm{~N}} \mathrm{HSP} 22-\mathrm{CIT}$ was more effectively attenuated by HSP20 and $\alpha$ B-Cry than by ${ }^{\text {wt } H S P 22}$ or ${ }^{\text {wt } H S P 27, ~ w h i l e ~}$ aggregate formation by ${ }^{\text {wt } H S P 22-C I T ~ w a s ~ m o s t ~ e f f e c t i v e l y ~}$ attenuated by $\alpha$ B-Cry and ${ }^{\text {wt }} \mathrm{HSP} 27$.

Collectively, these data indicate that both ${ }^{\mathrm{mu}} \mathrm{HSP} 22$ proteins have an increased tendency to form aggregates and that aggregation can be attenuated by ${ }^{\mathrm{wt}}$ sHSPs. The two ${ }^{\mathrm{mu}} \mathrm{HSP} 22$ proteins differ in their aggregate formation tendencies and in their responsiveness to attenuation by ${ }^{\mathrm{wt}} \mathrm{HSP} 22$ and other ${ }^{\mathrm{wt}}$ sHSPs, thus indicating different properties of the two ${ }^{\mathrm{mu}} \mathrm{HSP} 22$ forms.

These data also demonstrate that in all settings tested, a significant proportion of cells do not form aggregates by $24 \mathrm{~h}$ after transfection. In these cells, the sHSP-CIT/CFP fusion proteins show a relatively even cytoplasmic distribution. Such cells were selected for qFRET measurements, as described below.

\section{Disease-associated ${ }^{\mathrm{mu}} \mathrm{HSP} 22$ shows abnormal interaction with itself and with ${ }^{\text {wt }} \mathrm{HSP} 22$}

We have determined the ability of the two known ${ }^{\mathrm{mu}}$ HSP22 forms to interact with themselves and with

\footnotetext{
${ }^{1}$ Correspondence: Department of Cell and Developmental Biology, University of Michigan Medical School, 109 Zina Pitcher Place, Ann Arbor, MI 48109-2200, USA. E-mail: rbenndo@umich.edu doi: 10.1096/fj.06-5911fje
} 
${ }^{\text {wt HSP22 }}$ using the yeast two-hybrid (TH) method. The $\mathrm{TH}$ experiments indicated activation of the reporter genes in all interactions tested $\left({ }^{\mathrm{wt}} \mathrm{HSP} 22 /{ }^{\mathrm{wt}} \mathrm{HSP} 22\right.$; ${ }_{\mathrm{K} 141 \mathrm{E}}$ HSP22/ ${ }^{\mathrm{wt}} \mathrm{HSP} 22 ;{ }^{\mathrm{K} 141 \mathrm{~N}} \mathrm{HSP} 22$ / ${ }^{\mathrm{wt}} \mathrm{HSP} 22 ;{ }^{\mathrm{K} 141 \mathrm{E}} \mathrm{HSP} 22$ / $\left.{ }^{\mathrm{K} 141 \mathrm{E}} \mathrm{HSP} 22 ;{ }^{\mathrm{K} 141 \mathrm{~N}} \mathrm{HSP} 22 /{ }^{\mathrm{K} 141 \mathrm{~N}} \mathrm{HSP} 22\right)$. Thus, all HSP22 species interacted with one another. Within the limits of this method, no differences in the interaction intensities were observed as compared to the ${ }^{\mathrm{wt}} \mathrm{HSP} 22 /{ }^{\mathrm{wt}} \mathrm{HSP} 22$ control interaction.

To determine differences in the binding stoichiometry in these interactions, the more sensitive in vivo quantitative fluorescence resonance energy transfer (qFRET) method was applied. COS-7 cells were doubly transfected with pairs (CIT, CFP) of the various forms of HSP22 fusion protein cDNAs. The apparent average fluorescence resonance energy transfer efficiency (AAFE) values obtained for all tested interactions were significantly different from the negative control, thus indicating interaction (Fig. 1). The AAFE for the ${ }^{\mathrm{K} 141 \mathrm{E}} \mathrm{HSP} 22 /{ }^{\mathrm{wt}} \mathrm{HSP} 22$ interaction was similar to that of the ${ }^{\mathrm{wt}} \mathrm{HSP} 22 /{ }^{\mathrm{wt}} \mathrm{HSP} 22$ interaction, while the AAFE of the ${ }^{\mathrm{K} 141 \mathrm{E}} \mathrm{HSP} 22 /{ }^{\mathrm{K} 141 \mathrm{E}} \mathrm{HSP} 22$ interaction was moderately, though significantly, increased as compared to the ${ }^{\mathrm{wt}} \mathrm{HSP} 22 /{ }^{\mathrm{wt}} \mathrm{HSP} 22$ interaction. In contrast, K141N HSP22 showed a strongly (approximately twofold) increased AAFE in the interactions with both ${ }^{\text {wt HSP22 } 2 \text { and itself, as compared to }{ }^{\mathrm{wt}} \mathrm{HSP} 22 .}$

Cross-linking was also used to determine homodimer and oligomer formation of the various HSP22 species.

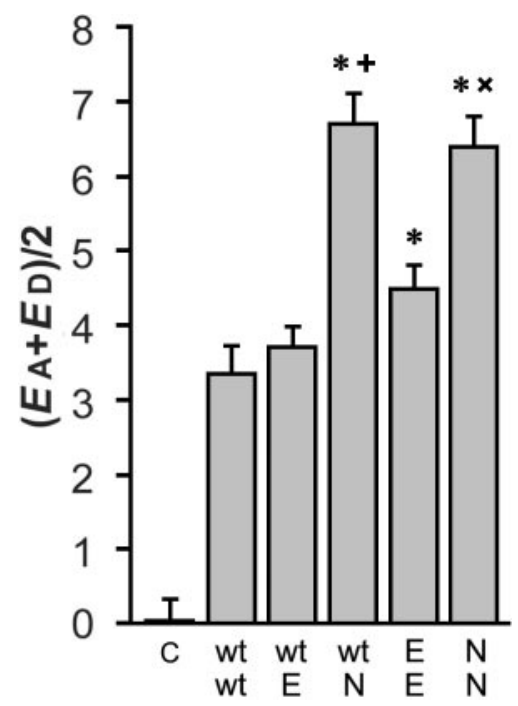

Figure 1. qFRET measurements of the interactions of ${ }^{\mathrm{K} 141 \mathrm{E}}$ HSP22 and ${ }^{\mathrm{K} 141 \mathrm{~N}} \mathrm{HSP} 22$ with ${ }^{\mathrm{wt}} \mathrm{HSP} 22$ and with themselves in doubly transfected COS-7 cells $24 \mathrm{~h}$ after transfection. The AAFE was determined in cells expressing the various HSP22 species as indicated. The HSP22 species were used as CIT (top row of the abscissa legend) and CFP fusion proteins (bottom row of the abscissa legend). All sample values were significantly different from the negative control (expression of CIT and CFP). Significant differences from the

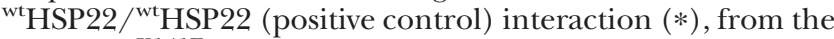
${ }^{\mathrm{wt}} \mathrm{HSP} 22 /{ }^{\mathrm{K} 141 \mathrm{E}} \mathrm{HSP} 22$ interaction $(+)$, and from the ${ }^{\mathrm{K} 141 \mathrm{E}} \mathrm{HSP} 22 /{ }^{\mathrm{K} 141 \mathrm{E}} \mathrm{HSP} 22$ interaction $(X)$ are indicated where appropriate. Abbreviations: C, control; wt, ${ }^{\mathrm{wt}} \mathrm{HSP} 22$; E, ${ }^{\mathrm{K} 11 \mathrm{E}} \mathrm{HSP} 22 ; \mathrm{N},{ }^{\mathrm{K} 141 \mathrm{~N}} \mathrm{HSP} 22$.

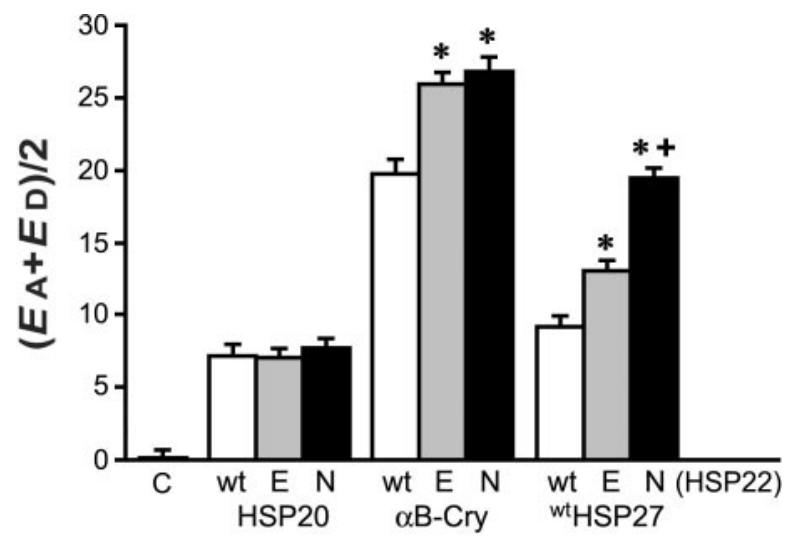

Figure 2. qFRET measurements of the interactions of ${ }^{\mathrm{K} 141 \mathrm{E}} \mathrm{HSP} 22$, ${ }^{\mathrm{K} 141 \mathrm{~N}} \mathrm{HSP} 22$, and ${ }^{\mathrm{wt}} \mathrm{HSP} 22$ (positive control) with HSP20, $\alpha \mathrm{B}-\mathrm{Cry}$, and ${ }^{\mathrm{wt}} \mathrm{HSP} 27$ in doubly transfected COS-7 cells $24 \mathrm{~h}$ after transfection. The AAFE was determined

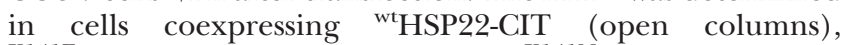
${ }^{\mathrm{K} 141 \mathrm{E}}$ HSP22-CIT (gray columns), or ${ }^{\mathrm{K} 141 \mathrm{~N}} \mathrm{HSP} 22-\mathrm{CIT}$ (solid columns) with HSP20-CFP, $\alpha$ B-Cry-CFP, and ${ }^{\text {wt } H S P 27-C F P . ~}$ All sample values were significantly different from the negative control (expression of CIT and CFP). Significant differ-

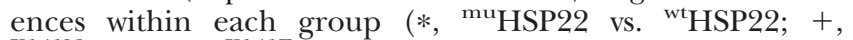
${ }^{\mathrm{K} 141 \mathrm{~N}}$ HSP22 vs. $\left.{ }^{\mathrm{K} 141 \mathrm{E}} \mathrm{HSP} 22\right)$ are indicated. Abbreviations are as in Fig. 1.

HEK-293T cells were transfected with vectors to express myc-tagged ${ }^{\mathrm{wt}} \mathrm{HSP} 22$, ${ }^{\mathrm{K} 141 \mathrm{E}} \mathrm{HSP} 22$, or ${ }^{\mathrm{K} 141 \mathrm{~N}} \mathrm{HSP} 22$. Forty-eight hours later, cells were treated with disuccinimidyl suberate, a homobifunctional cross-linker. The analysis of the cross-linked proteins by SDS-PAGE/ Western blotting revealed that ${ }^{\mathrm{wt}} \mathrm{HSP} 22,{ }^{\mathrm{K} 141 \mathrm{E}} \mathrm{HSP} 22$, and ${ }^{\mathrm{K} 141 \mathrm{~N}} \mathrm{HSP} 22$ form homodimers and possibly tetramers. No major differences between ${ }^{\mathrm{wt}} \mathrm{HSP} 22$ and ${ }^{\mathrm{mu}} \mathrm{HSP} 22$ were observed.

Collectively, the TH, qFRET, and cross-linking data suggest that the mu HSP22 proteins interact with

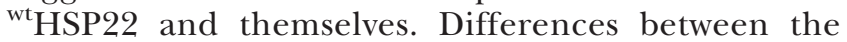
${ }^{\mathrm{mu}} \mathrm{HSP} 22$ forms and ${ }^{\mathrm{wt}} \mathrm{HSP} 22$ could be demonstrated by the qFRET method due to its greater sensitivity.

\section{Disease-associated ${ }^{\mathrm{mu} H S P 22}$ shows abnormal interaction with other sHSPs}

HSP22 is known to interact with HSP20, $\alpha \mathrm{B}-\mathrm{Cry}$, and

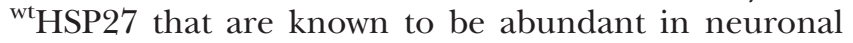
cells. To determine potentially aberrant interaction properties with these sHSPs, both ${ }^{\text {mu}}$ HSP22 forms were probed in TH and qFRET assays. The TH data suggested that both ${ }^{\mathrm{K} 141 \mathrm{E}} \mathrm{HSP} 22$ and ${ }^{\mathrm{K} 141 \mathrm{~N}} \mathrm{HSP} 22$ interact with HSP20, $\alpha \mathrm{B}-\mathrm{Cry}$, and ${ }^{\mathrm{wt}} \mathrm{HSP} 27$. Within the limits of this method, no differences in the interaction intensities between ${ }^{\mathrm{mu}} \mathrm{HSP} 22$ and ${ }^{\mathrm{wt}} \mathrm{HSP} 22$ were observed.

The qFRET analysis in doubly transfected COS-7 cells was performed as described above using CIT- and CFP-sHSP fusion proteins. The AAFE values for both ${ }^{\mathrm{K} 141 \mathrm{E}}$ HSP22 and ${ }^{\mathrm{K} 141 \mathrm{~N}} \mathrm{HSP} 22$ with HSP20 as interacting partner were not significantly different from that of

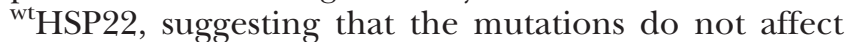
this interaction (Fig. 2, HSP20 group). In contrast, the 
Figure 3. Schematic of identified abnormal interactions at the dimer level involving diseaseassociated ${ }^{\mathrm{K} 141 \mathrm{E}} \mathrm{HSP} 22, \quad{ }^{\mathrm{K} 141 \mathrm{~N}} \mathrm{HSP} 22$, and ${ }^{\mathrm{S} 135 \mathrm{~F}} \mathrm{HSP} 27$. Single interactions were found unchanged (-), moderately increased (-), or greatly increased $(\boldsymbol{m})$ in comparison with the
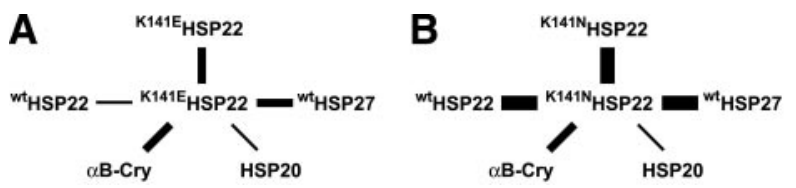
C

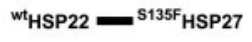
corresponding wild-type sHSPs in the same interaction. A) ${ }^{\mathrm{K} 141 \mathrm{E}} \mathrm{HSP} 22$ has moderately increased interactions with itself, $\alpha \mathrm{B}-\mathrm{Cry}$,

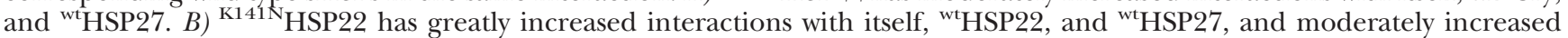
interaction with $\alpha$ B-Cry. $C$ ) ${ }^{\mathrm{S} 135 \mathrm{~F}} \mathrm{HSP} 27$ has moderately increased interaction with ${ }^{\mathrm{wt}} \mathrm{HSP} 22$. Note that each ${ }^{\mathrm{mu}} \mathrm{HSP} 22 \mathrm{form}$ has a characteristic, abnormal interaction pattern. That ${ }^{\mathrm{mu}} \mathrm{HSP} 22$ has increased interaction with ${ }^{\text {wt }} \mathrm{HSP} 27$ and that ${ }^{\mathrm{S} 135 \mathrm{~F}} \mathrm{HSP} 27$ has increased interaction with ${ }^{\text {wt }}$ HSP22 and mutations in HSP22 or HSP27 resulting in a similar disease suggest that both mutant proteins may act through the same mechanism.

AAFE values for both ${ }^{\mathrm{K} 141 \mathrm{E}} \mathrm{HSP} 22$ and ${ }^{\mathrm{K} 141 \mathrm{~N}} \mathrm{HSP} 22$ with $\alpha \mathrm{B}-\mathrm{Cry}$ as interacting partner were moderately, although significantly, increased ( $\alpha \mathrm{B}-\mathrm{Cry}$ group) as com-

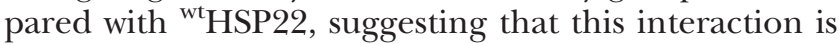
affected by both mutations. The AAFE values for both ${ }^{\mathrm{mu}} \mathrm{HSP} 22$ proteins were similar when compared to each other. Finally, the AAFE values for ${ }^{\mathrm{K} 141 \mathrm{E}} \mathrm{HSP} 22$ and ${ }^{\mathrm{K} 141 \mathrm{~N}} \mathrm{HSP} 22$ were moderately and strongly increased, respectively, with HSP27 as interacting partner (HSP27

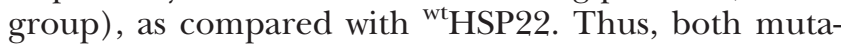
tions result in increased interaction with HSP27, although to a different extent.

\section{Disease-associated ${ }^{\mathrm{S} 135 \mathrm{~F}} \mathrm{HSP} 27$ shows abnormal interaction with ${ }^{\text {wt }} \mathrm{HSP} 22$}

dHMN and CMT are clinically and genetically heterogeneous groups of neuropathies. In addition to mutations in HSP22, several mutations in HSP27 $\left({ }^{\mathrm{mu}} \mathrm{HSP} 27\right.$ ) have been identified that are also associated with dHMN and CMT. Because ${ }^{\mathrm{mu}} \mathrm{HSP} 27$ may affect the HSP22/HSP27 interaction in a manner similar to ${ }^{m u} H S P 22$, one of the known ${ }^{\text {mu}} \mathrm{HSP} 27$ forms ( $\left.{ }^{\mathrm{S} 135 \mathrm{~F}} \mathrm{HSP} 27\right)$ was also included in these experiments. The TH data showed that ${ }^{\mathrm{S} 135 \mathrm{~F}} \mathrm{HSP} 27$ interacts with

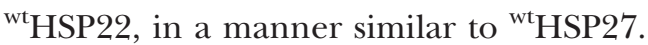

For the qFRET analysis, COS-7 cells were doubly transfected to express ${ }^{\mathrm{S} 135 \mathrm{~F}} \mathrm{HSP} 27-\mathrm{CIT}$ or ${ }^{\mathrm{wt}} \mathrm{HSP} 27-\mathrm{CIT}$

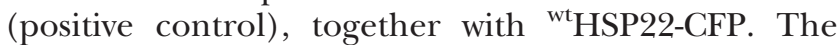
AAFE values obtained for the interactions of ${ }^{\mathrm{S} 135 \mathrm{~F}}$ HSP27 and ${ }^{\text {wt }} \mathrm{HSP} 27$ with ${ }^{\mathrm{wt}} \mathrm{HSP} 22$ were significantly different from the negative control, thus indicating interaction. The AAFE for the ${ }^{\mathrm{S} 135 \mathrm{~F}} \mathrm{HSP} 27 /{ }^{\mathrm{wt}} \mathrm{HSP} 22$ interaction was significantly greater than for the ${ }^{\text {wt HSP27 }} /{ }^{\mathrm{wt}} \mathrm{HSP} 22$ interaction. Thus, this ${ }^{\mathrm{mu}} \mathrm{HSP} 27$ form affects the HSP22/HSP27 interaction in a similar way as the two studied ${ }^{\text {mu} H S P 22}$ forms do.

\section{CONCLUSION AND SIGNIFICANGE}

This work shows that both disease-associated forms of ${ }^{\mathrm{mu}} \mathrm{HSP} 22$ interacted with ${ }^{\mathrm{wt}} \mathrm{HSP} 22$, with themselves, and with the other sHSPs HSP20, $\alpha \mathrm{B}-\mathrm{Cry}$, and HSP27. The stoichiometry of some of the analyzed interactions was increased, while others remained unchanged. None of the interactions was weakened. Each of the two ${ }^{\mathrm{mu}}$ HSP22 forms had a characteristic pattern of aberrant interactions. The interaction characteristics of ${ }^{\mathrm{K} 141 \mathrm{~N}}$ HSP22 deviated more from ${ }^{\mathrm{wt}} \mathrm{HSP} 22$ than those of ${ }^{\mathrm{K} 141 \mathrm{E}} \mathrm{HSP} 22$. Whether this correlates to the clinical phenotype, e.g., the severity of the associated diseases, remains to be determined. The aberrant interactions of ${ }^{\mathrm{mu}} \mathrm{HSP} 22$ proteins may relate to their increased ability to form aggregates. The more aberrant interaction properties of ${ }^{\mathrm{K} 141 \mathrm{~N}} \mathrm{HSP} 22$ may explain the greatly increased formation of aggregates. One of the dHMNand CMT-associated HSP27 mutants ( $\left.{ }^{\mathrm{S} 135 \mathrm{~F}} \mathrm{HSP} 27\right)$ was also found to have an abnormally increased interaction with ${ }^{\text {wt }} \mathrm{HSP} 22$. A summary of the identified abnormal interactions of ${ }^{\mathrm{K} 141 \mathrm{E}} \mathrm{HSP} 22,{ }^{\mathrm{K} 141 \mathrm{~N}} \mathrm{HSP} 22$, and ${ }^{\mathrm{S} 135 \mathrm{~F}}$ HSP27 is given in Fig. $\mathbf{3} \boldsymbol{A}, \boldsymbol{B}$, and $\boldsymbol{C}$, respectively.

The facts that HSP22 and HSP27 are interacting proteins and that either ${ }^{\mathrm{mu} H S P} 22$ or ${ }^{\mathrm{mu}} \mathrm{HSP} 27$ result in similarly increased interaction between both proteins, support the hypothesis that mutations in either protein affect the same pathway or protein complex. All known mutations in HSP22 and HSP27 have dominant gainof-function characteristics, and the presence of the ${ }^{\mathrm{wt}} \mathrm{sHSPs}$ in the diseased tissues cannot prevent the development of the diseases. A plausible explanation is that insertion of only a few mutated protein molecules into the sHSP complexes may result in the formation of malstructured and thus malfunctioning complexes. Thus, the model based on aberrant sHSP interactions may provide the rationale for the genetic dominance as is seen in these diseases.

In summary, the data presented here may provide the rationale for the pathogenesis of the mutant sHSPassociated motor neuropathies $\mathrm{dHMN}$ and CMT. The molecular and cellular events by which the abnormal interactions and aggregate-forming properties of ${ }^{\mathrm{mu}}$ HSP22 translate finally into the slow death of motor neurons remain to be elucidated. 